\title{
NADPH Oxidase and the Degeneration of Dopaminergic Neurons in Parkinsonian Mice
}

\author{
Marina S. Hernandes, Cecília C. Café-Mendes, and Luiz R. G. Britto \\ Department of Physiology and Biophysics, Institute of Biomedical Sciences, University of São Paulo, \\ São Paulo, 05508-900 SP, Brazil
}

Correspondence should be addressed to Marina S. Hernandes; marina_sorrentino@yahoo.com.br

Received 9 August 2013; Revised 8 October 2013; Accepted 23 October 2013

Academic Editor: Tiago Fleming Outeiro

Copyright (C) 2013 Marina S. Hernandes et al. This is an open access article distributed under the Creative Commons Attribution License, which permits unrestricted use, distribution, and reproduction in any medium, provided the original work is properly cited.

\begin{abstract}
Several lines of investigation have implicated oxidative stress in Parkinson's disease (PD) pathogenesis, but the mechanisms involved are still unclear. In this study, we characterized the involvement of NADPH oxidase (Nox), a multisubunit enzyme that catalyzes the reduction of oxygen, in the 6-hydroxydopamine- (6-OHDA-) induced PD mice model and compared for the first time the effects of this neurotoxin in mice lacking gp $91^{\text {phox-/- }}$, the catalytic subunit of Nox2, and pharmacological inhibition of Nox with apocynin. Six-OHDA induced increased protein expression of $47^{\text {phox }}$, a Nox subunit, in striatum. gp91 ${ }^{\text {phox- } /-}$ mice appear to be completely protected from dopaminergic cell loss, whereas the apocynin treatment conferred only a limited neuroprotection. Wt mice treated with apocynin and gp91 ${ }^{\text {phox- } /-}$ mice both exhibited ameliorated apomorphine-induced rotational behavior. The microglial activation observed within the striatum and the substantia nigra pars compacta (SNpc) of 6-OHDA-injected Wt mice was prevented by apocynin treatment and was not detected in gp91 ${ }^{\text {phox- } /-}$ mice. Apocynin was not able to attenuate astrocyte activation in SN. The results support a role for Nox2 in the 6-OHDA-induced degeneration of dopaminergic neurons and glial cell activation in the nigrostriatal pathway and reveal that no comparable 6-OHDA effects were observed between apocynin-treated and gp91 $91^{\text {phox-l- }}$ mice groups.
\end{abstract}

\section{Introduction}

Parkinson's disease (PD) is characterized by a progressive loss of dopaminergic neurons in the nigrostriatal pathway of the brain, which triggers complex functional modifications within the basal ganglia circuitry. The decline of dopamine in the striatum is clinically associated with the typical motor symptoms of the disease, such as bradykinesia, tremor, rigidity, and postural instability $[1,2]$.

Although the etiology of PD is unknown, a common element of most theories is the involvement of oxidative stress, either as a primary or secondary event of the disease $[2,3]$. Indeed, analysis of postmortem human brain tissue obtained from PD patients revealed elevated levels of the oxidative stress products such as 4-hydroxynonenal [4], protein carbonyls [5, 6], and 3-nitrotyrosine [7, 8].

Research on the pathogenesis of PD has rapidly advanced due to the development of animal models, which have largely contributed to the understanding of the progression of PD and to the development of potential therapeutic strategies [9, 10]. Although several toxin-induced animal models simulate the motor deficits occurring in PD, 6-hydroxydopamine (6OHDA) lesions have been the most widely used animal models of PD since the 1970s, after the demonstration that the injection of this agent into the substantia nigra pars compacta $(\mathrm{SNpc})$ was able to cause anterograde degeneration of the nigrostriatal dopaminergic system [11]. Ever since, the 6-OHDA model has been accepted as a valuable tool for replicating the PD-like loss of dopaminergic neurons in the SNpc [10]. The biological effects of 6-OHDA were considered to be mainly related to the massive oxidative stress caused by the toxin that, once accumulated in the cytosol, seems to be autooxidated, promoting a high rate of free radical generation [9]. However, an in vitro study using apocynin, a nonspecific pharmacological inhibitor of NADPH oxidase (Nox), suggested that Nox-derived reactive 
oxygen species (ROS) might be also involved in the 6-OHDAinduced dopaminergic degeneration [12].

Noxes are multisubunit enzymes able to transfer electrons across biological membranes, reducing molecular oxygen to superoxide at the expense of NADPH. The prototype Nox, the Nox2 isoform, is composed of the membrane subunits gp91 $1^{\text {phox }}$ and $\mathrm{p} 22^{\text {phox }}$ and of cytosolic subunits $\mathrm{p} 47^{\text {phox }}$, $\mathrm{p} 67^{\text {phox }}, \mathrm{p} 40^{\text {phox }}$, and the small GTPase Rac. Nox 2 is activated by forming a complex with its cytosolic activators. Upon activation, $\mathrm{p} 47^{\text {phox }}$ becomes phosphorylated and the entire cytosolic complex translocates to the membrane, assembling with gp $91^{\text {phox }}$ and $\mathrm{p} 22^{\text {phox }}$, thus forming a functional Nox complex capable of reducing oxygen to superoxide [13]. It has been demonstrated that forty-eight hours after intrastriatal 6OHDA injection, gp $91^{\text {phox }}$ and $\mathrm{p} 47^{\text {phox }} \mathrm{mRNAs}$ were found to be increased in the rat ventral midbrain and striatum. There are demonstrations that Nox subunits are expressed in dopaminergic neurons in rat primary mesencephalic cultures and, most importantly, that the dopaminergic degeneration induced by 6-OHDA was significantly reduced by the treatment with apocynin [12].

Apocynin is a natural organic compound widely used as a Nox inhibitor. It is thought to prevent the translocation of cytosolic subunits to the membrane bound subunit gp91 ${ }^{\text {phox }}$, thus inhibiting the activation of the enzymatic complex and, consequently, the superoxide production [14]. Despite the positive effects of apocynin in experimental PD studies, its mechanism of action is still controversial. Furthermore, apocynin has multiple side effects, altering the cellular glutathione levels and interfering with many cellular signaling cascades [15]. In light of those facts, the main purpose of this study was to characterize the involvement of Nox2 in the 6OHDA-induced PD mouse model by comparing the effects of that neurotoxin on mice lacking $\mathrm{gp} 91^{\text {phox }}$, the catalytic subunit of Nox2, and the pharmacological inhibition of Nox with apocynin. Behavioral testing, immunohistochemistry, and Western blotting assays were combined in order to evaluate that issue.

\section{Materials and Methods}

2.1. Animals. Ten-week-old male gp $91^{\text {phox-/- }}$ mice (Jackson Laboratories, Maine, USA), along with wild type (Wt) mice (C57BL/6) weighing between 25 and 30 g, were used throughout this study. The animals had free access to food and water and were maintained on a 12-12 h light-dark cycle. Experiments were performed with age- and weight-matched animals. All procedures were approved by the Institutional Animal Care Committee of the Institute of Biomedical Sciences, University of São Paulo, Brazil.

2.2. Surgical Procedures. In order to lesion the nigrostriatal system, 6-OHDA was unilaterally injected into the right striatum of both gp91 ${ }^{\text {phox-/- }}$ and Wt mice. The animals were anaesthetized using 2, 2, 2-tribromoethanol (2\%, SigmaAldrich Co., St. Louis, MO, USA) and placed into a stereotaxic frame with nose and ear bars especially designed for mice.
six-OHDA (Sigma Chemical Co., St. Louis, MO, USA) was dissolved at a concentration of $10 \mu \mathrm{g} / \mu \mathrm{L}$ in saline $(\mathrm{NaCl} 0.9 \%)$ with $0.1 \%$ ascorbic acid [16]. The injection was performed using a Hamilton syringe (model 701) at the following coordinates: AP: $-0.4 \mathrm{~mm}$; ML: $\pm 2.0 \mathrm{~mm}$; DV: $-3.0 \mathrm{~mm}$ relative to the bregma [17]. The total volume injected was $1 \mu \mathrm{L}$. The injection was conducted at a rate of $0.5 \mu \mathrm{L} / \mathrm{min}$ and the needle was left in place for additional 3 min before it was slowly removed. The left striatum received $1 \mu \mathrm{L}$ of vehicle (saline in $0.1 \%$ ascorbic acid) in the same coordinates and was used as a control. Additionally, sham-operated mice were infused with $1 \mu \mathrm{L}$ of vehicle into both right and left striatum and served as controls in the apomorphine-induced rotation test. Clinical signs were also monitored daily after the surgery, including general body condition and dehydration. Behavioral analyses were typically conducted during the morning hours.

Animals used for immunohistochemistry to detect glial cell markers $(n=23)$ and for immunoblotting $(n=8)$ were euthanized for analysis 15 days after the surgery. An additional group of mice was subjected to the apomorphineinduced rotation test $(n=27)$ and their brains were used for immunohistochemical assays to detect tyrosine hydroxylase (TH).

2.3. Apomorphine-Induced Rotation Test. Apomorphine (Tocris Bioscience, Ellisville, MO, USA) was injected i.p. at a dose of $0.1 \mathrm{mg} / \mathrm{kg}$ [18]. Mice were placed in an automated rotameter (Rota-count, Columbus Instruments, Columbus, $\mathrm{OH}$, USA) and allowed to adapt to their environment for $5 \mathrm{~min}$ before the rotations were recorded over $10 \mathrm{~min}$. Results were expressed as number of rotations to the side contralateral to the lesion per minute.

2.4. Apocynin Treatment. Wt mice were treated with apocynin $(200 \mathrm{mg} / \mathrm{kg} /$ day in the drinking water; [19] for 15 days after 6-OHDA injections).

2.5. Immunoblotting. For subcellular fractionation (membrane and cytosolic protein fractions), mesencephalic and striatal samples were quickly collected, frozen in liquid nitrogen, and stored at $-70^{\circ} \mathrm{C}$ until use. Briefly, tissue proteins were isolated in $50 \mathrm{mM}$ Tris $\mathrm{HCl}, 150 \mathrm{mM} \mathrm{NaCl}, 2 \mathrm{mM}$ EDTA, $0.5 \%$ sodium deoxycholate, $2 \mathrm{mM}$ sodium fluoride, $1 \%$ SDS, $1 \%$ Nonidet P-40, and protease inhibitors (Sigma-Aldrich Co., St. Louis, MO, USA). Homogenates were centrifuged for $10 \mathrm{~min}$ at $2,000 \times \mathrm{g}$ at $4^{\circ} \mathrm{C}$. The supernatants were collected and submitted to ultracentrifugation for $1 \mathrm{~h}$ at $100,000 \times \mathrm{g}$ at $4^{\circ} \mathrm{C}$. The resulting supernatants and pellets were designated as the cytosolic and membrane fractions, respectively. The protein concentration was determined using the Bradford method (Bio-Rad, CA, USA) and 10\% acrylamide SDS gels (Bio-Rad, CA, USA) were loaded with $30 \mu \mathrm{g}$ of protein per lane. These proteins were then electrotransferred to nitrocellulose membranes (Millipore, Billerica, MA, USA) at $100 \mathrm{~V}$ for $80 \mathrm{~min}$ using a Trans-Blot cell. The membranes were then blocked for 2 hours at room temperature with phosphate buffered saline (PBS) containing 0.05\% Tween-20 (TTBS) and 5\% nonfat milk and incubated 
overnight at $4^{\circ} \mathrm{C}$ with anti- $47^{\text {phox }}$ (Chemicon, USA) diluted 1:1000 in TTBS with $1 \%$ nonfat milk. The probed proteins were developed by using a chemiluminescent kit (ECL, Amersham Biosciences, NJ, EUA) and the bound antibodies were visualized using radiographic films. Loading controls were evaluated by antiactin (1:1000 - Sigma, EUA) blotting when cellular extracts were analyzed, and by anti-integrin (1:2000 - Abcam, EUA) when membrane fractions were analyzed. The quantification of band intensity was performed with ImageJ (National Institutes of Health, USA).

2.6. Immunoperoxidase. Mice were deeply anesthetized with ketamine hydrochloride $(100 \mathrm{mg} / \mathrm{kg}$ of body weight, i.m.) and xylazine $(16 \mathrm{mg} / \mathrm{kg}$ of body weight, i.m.) and subjected to transcardiac perfusion, with a buffered saline solution, followed by a fixative solution containing $4 \%$ paraformaldehyde (PFA) dissolved in $0.1 \mathrm{M}$ phosphate buffer ( $\mathrm{PB}, \mathrm{pH}$ 7.4). The brains were collected, postfixed in PFA for $4 \mathrm{~h}$, and transferred to a $30 \%$ sucrose solution in $\mathrm{PB}$ to ensure cryoprotection, which lasted for $48 \mathrm{~h}$. Brain sections were obtained on a sliding microtome adapted for cryosectioning. The $30 \mu \mathrm{m}$-thick coronal sections were collected in PB and arranged in 6 similar sets. Sections were incubated for 12-16 h with anti-OX42 (CD11b/c, Biosciences, CA, USA), anti-GFAP (Immunon, Pittsburgh, PA, USA), and anti-TH (Chemicon, Temecula, CA, USA) diluted $1: 1000$ in $0.3 \%$ of Triton X100, containing $0.05 \%$ normal donkey serum. Following 3 washes of 10 min each with $\mathrm{PB}$, sections were incubated for $2 \mathrm{~h}$ with a biotinylated secondary antibody (donkey anti-mouse IgG, Jackson ImmunoResearch, PA,USA, 1:200), then with the avidin-biotin complex $(1: 100$; ABC Elite kit, Vector Labs, Burlingame, CA, USA). After washing, the sections reacted with $0.05 \%$ 3,3-diaminobenzidine and $0.01 \%$ hydrogen peroxide in PB. Intensification was conducted with $0.05 \%$ osmium tetroxide in water. The sections were mounted on gelatinized slides, dehydrated, cleared, and coverslipped. Controls for immunostaining included the omission of the primary antibody and its substitution for normal goat serum, which completely eliminated staining.

2.7. Glial Cell Image Acquisition and Quantification. Digital images were acquired for both striatum and SN on a light microscope. Each slide was scanned at 20x magnification. A total of eight sampling areas from the control and experimental striatum and SN from eight animals were acquired for analysis. Semiquantitative skeleton analysis method was performed using ImageJ software [20]. For skeleton analysis, the image threshold was adjusted to exclude background labeling and to visualize all glial cells and processes (OX42 and GFAP immunostaining); thresholding values were kept constant between matching control and experimental regions. The resulting image was converted to a binary, skeletonized and evaluated in terms of optical density. The results for each one of the experimental groups (Wt, gp91phox ${ }^{-/-}$and $\mathrm{Wt}$ treated with apocynin) were then averaged and subjected to statistical analysis using GraphPad Prism 3.02 (GraphPad Software Inc., San Diego, CA, USA).
2.8. Immunofluorescence. In order to determine the expression of $\mathrm{p} 47^{\text {phox }}$ in specific cell types, double-labeling experiments were carried out using purified antibodies designed to label neurons (NeuN), astrocytes (glial fibrillary acidic protein, GFAP), and microglial cells (OX42). Immunofluorescence tissue preparation was performed in the same conditions as in the immunoperoxidase assays, described above. Briefly, the brain sections were incubated free floating for $12-16 \mathrm{~h}$ with the following primary antibodies: mouse antirat GFAP (1:1000 - Millipore, Billerica, MA, USA), mouse anti-rat OX42 (1:1000 - Abcam, Cambridge, UK), mouse anti-rat NeuN (1:1000 - Chemicon, Billerica, MA, USA), and mouse anti-rabbit $\mathrm{p} 47^{\text {phox }}(1: 250$ - Chemicon, Billerica, MA, USA) diluted in $0.3 \%$ of Triton X-100. Anti-rabbit FITC conjugated $(1: 250$; Abcam, Cambridge, UK) and antimouse TRITC conjugated (1:250; Abcam, Cambridge, UK) secondary antibodies were used. The sections were mounted on gelatinized slides and were coverslipped. Negative controls were performed by the omission of primary antibody; no staining was observed in these cases.

2.9. Immunofluorescence Image Acquisition and Quantification. Single scanned images were acquired by using a confocal Zeiss LSM 510 microscope. To quantify the percentage of cells expressing $\mathrm{p} 47^{\text {phox }}$ in the striatum and $\mathrm{SN}$, we acquired images doubly immunolabeled with antibodies specific to detect different cell types (neurons, astrocytes, and microglial cells) and to detect $\mathrm{p} 47^{\text {phox }}$. A total of eight sampling areas from the control and experimental striatum and SN of each one of the five animals were acquired for analysis. Each slide was scanned at 20x magnification. The red and merged channels from each sampling area were opened in two separate layers of the ImageJ software and compared [21]. By using the ImageJ cell counter plug-in, $\mathrm{p} 47^{\text {phox }}$ immunopositive cells were labeled manually with a colored square, as well as the total number of cells. A ratio was established between the number of $\mathrm{p} 47^{\text {phox }}$ immunolabeled cells and the total amount of cells in the same sampling area, resulting in the percentage of labeled cells. The results were averaged and subjected to statistical analysis using the software GraphPad Prism 3.02. Manipulation of the images was restricted to threshold and brightness adjustments to the whole image.

2.9.1. Semiquantitative Analyses of TH-Immunoreactive Fibers in the Striatum and TH-Immunoreactive Cell Bodies in the SNpc. The numbers of TH-labeled cells in the SNpc were determined by serial section analysis of digital images obtained from stained brain sections using ImageJ (National Institutes of Health, USA). The third section series was sampled, which was supposed to include a representative sample of the SNpc area affected by the striatal 6-OHDA injection. Five sections at a distance of approximately $180 \mu \mathrm{m}$ from each other were analyzed for the cell counts. Measurements taken from each control and experimental condition from different experimental groups (Wt, gp91phox ${ }^{-1-}$, and $\mathrm{Wt}$ treated with apocynin) were averaged and subjected to statistical analysis using the software GraphPad Prism 3.02. The cell loss in the 

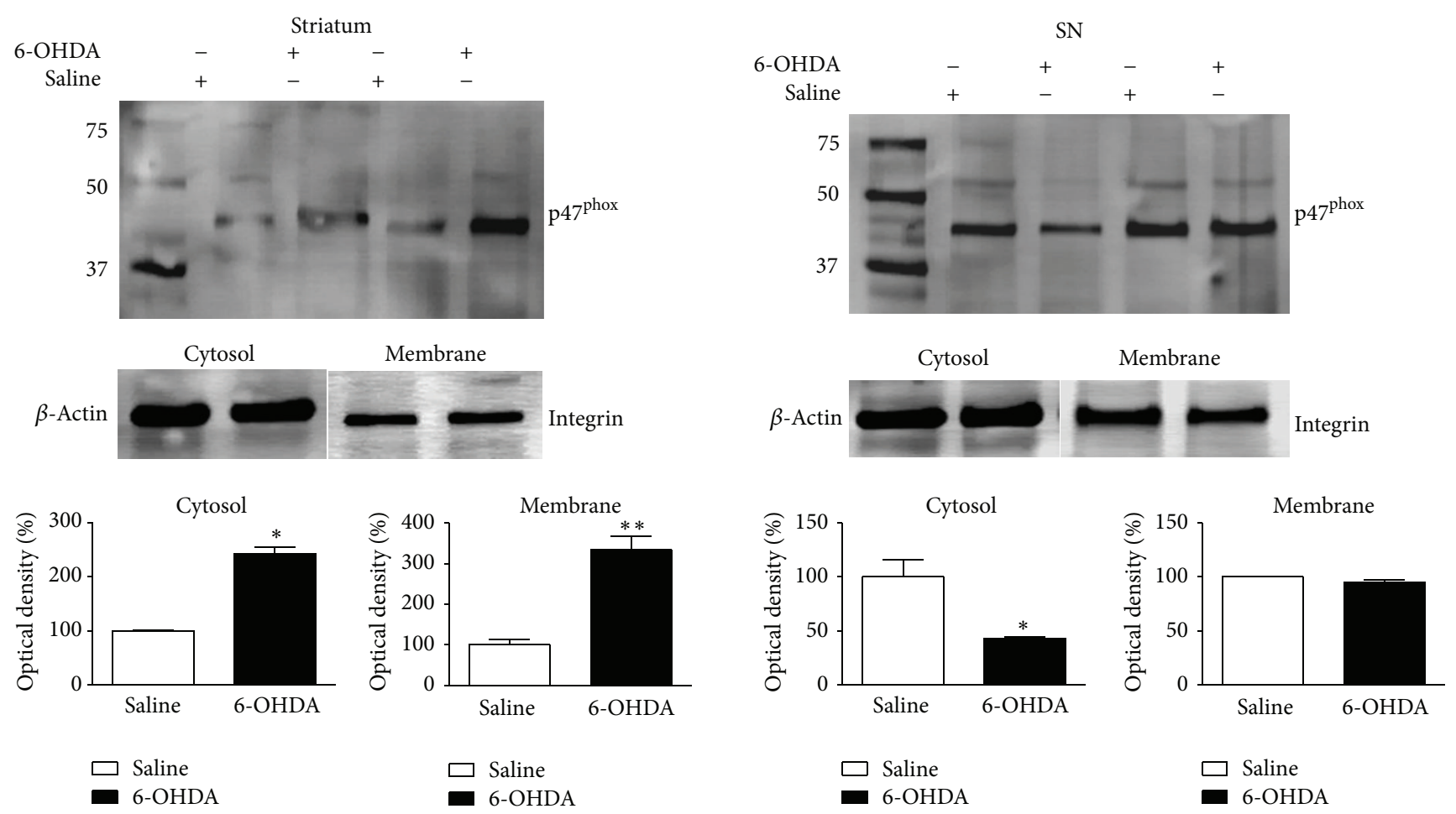

(a)
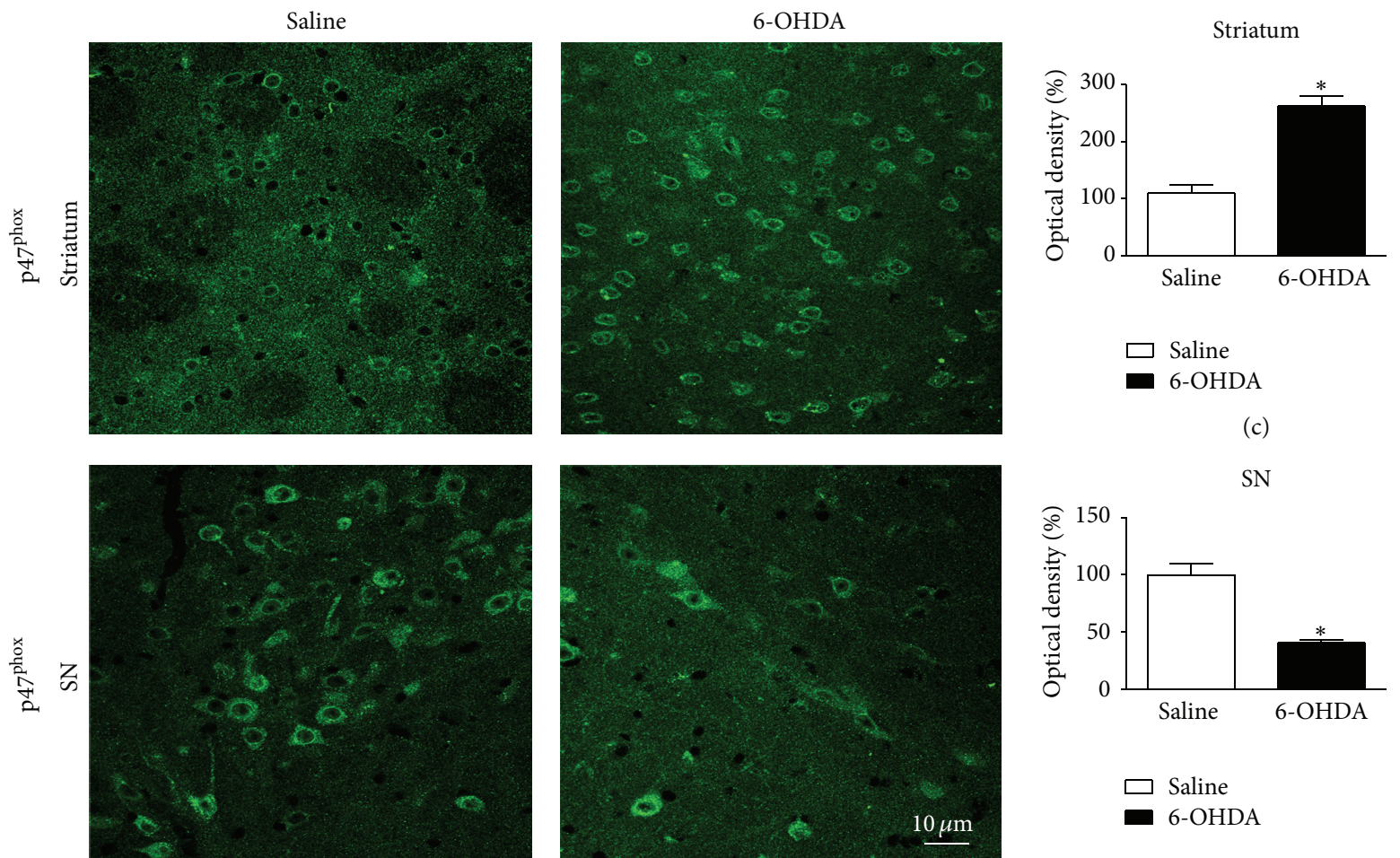

(c)

SN

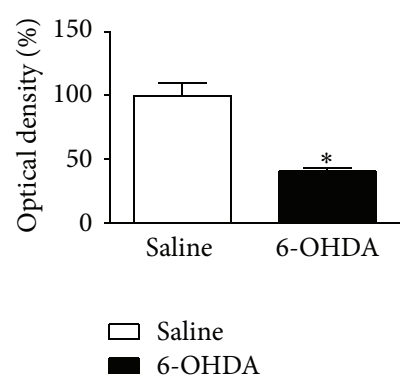

(b)

(d)

FIGURE 1: Effect of 6-OHDA on NADPH oxidase activation in SNpc and striatum. (a) representative Western blots illustrating that 6-OHDA stimulates NADPH-oxidase activation, as evidenced by $47^{\text {phox }}$ translocation from the cytosol to the plasma membrane in striatum samples of Wt mice. (b) representative confocal microscopy images illustrating $\mathrm{p} 47^{\text {phox }}$ immunostaining in striatum and SNpc of Wt mice. In (c) and (d), the graphs depict the mean optical density data of 5 samples in each case. ${ }^{*} P<0.05$ (Wt saline versus Wt 6-OHDA). 

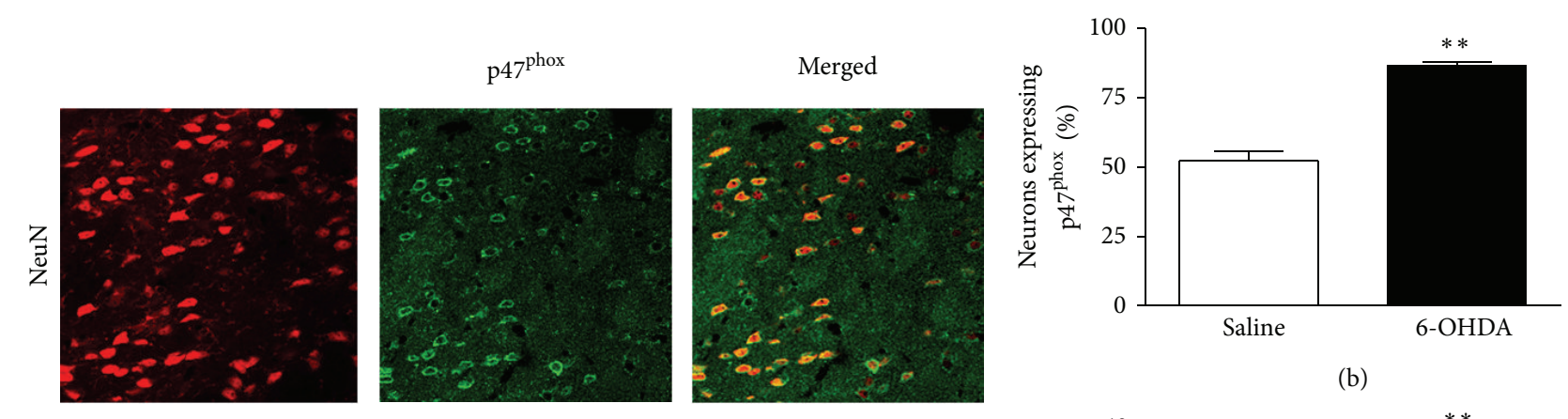

(b)
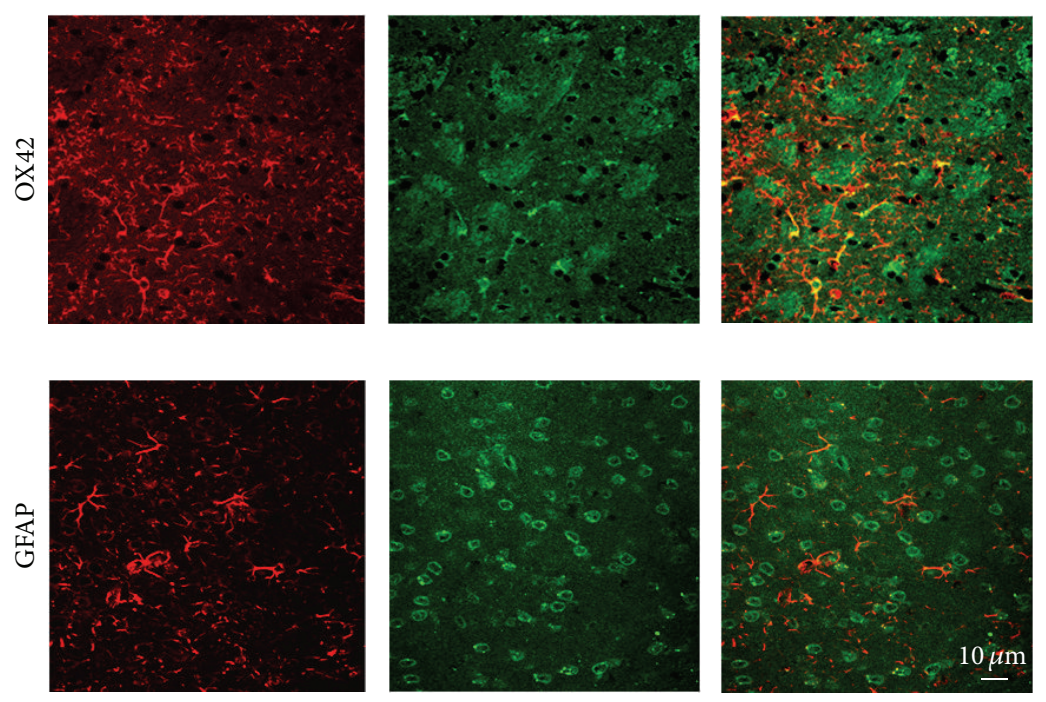

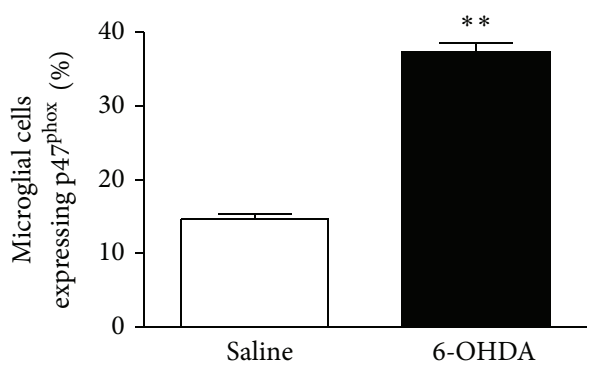

(c)

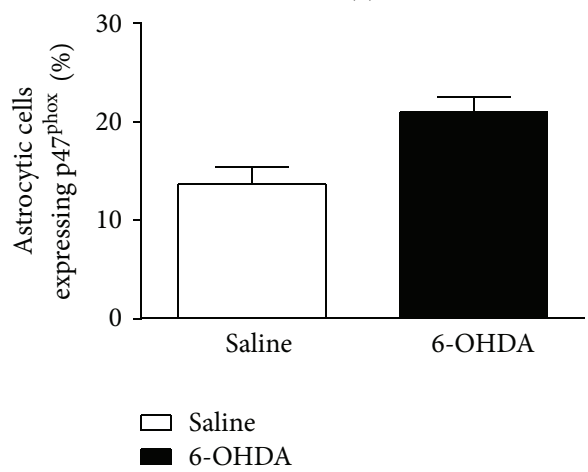

(d)

FIGURE 2: Expression of $\mathrm{p} 47^{\text {phox }}$ in striatum of Wt mice after 6-OHDA injection. (a) representative p47 $7^{\text {phox }}$ immunostaining in neurons and microglia in striatum. Immunostaining was carried out using antibodies for $\mathrm{p} 47^{\text {phox }}$ (shown in green) together with NeuN (top), OX42 (middle), and GFAP (bottom). Microglia, astrocytes, and neuronal markers are shown in red. In striatum, p47 $7^{\text {phox }}$ is expressed in neurons, microglial cells, and rarely with astrocytes. In (b), (c), and (d) the graphs represent the percentage of neurons, microglial cells and astrocytic cells expressing $\mathrm{p} 47^{\text {phox }}$, respectively. ${ }^{* *} P<0.01$ (Wt saline versus Wt 6-OHDA).

6-OHDA-lesioned side is expressed as the percentage of the cell number in the control (unlesioned) side.

Striatal TH immunoreactivity was evaluated in terms of optical density. The mean density of neighboring, nonlabeled areas in the same sections was used to normalize $\mathrm{TH}$ immunoreactivity. The resulting indexes for the control and experimental conditions from different experimental groups (Wt, gp91phox ${ }^{-/-}$, and Wt treated with apocynin) were then compared and subjected to statistical analysis using GraphPad Prism 3.02.

2.9.2. Statistical Analysis. Results are presented as the mean \pm standard errors (SEM). Statistical analyses of data were generated using GraphPad Prism, version 3.02 (GraphPad Software Inc., San Diego, CA, USA). For individual comparisons, statistical analysis was performed using unpaired Student's $t$-test. Statistical comparison of more than two groups was performed using analysis of variance (ANOVA), followed by Tukey's test. In all cases, $P \leq 0.05$ was considered statistically significant.

\section{Results}

3.1. NADPH Oxidase Activation. The NADPH oxidase complex includes cytosolic components such as $\mathrm{p} 67^{\text {phox }}$ and p $47^{\text {phox }}$ and membrane components [22]. Considering that activation of this enzyme requires the translocation of its cytosolic subunits to the plasma membrane, we first assessed whether 6-OHDA induced increased $\mathrm{p} 47^{\text {phox }}$ subunit in plasma membrane fractions. Fifteen days after 6-OHDA injection, striatum and $\mathrm{SN}$ tissue samples were separated 

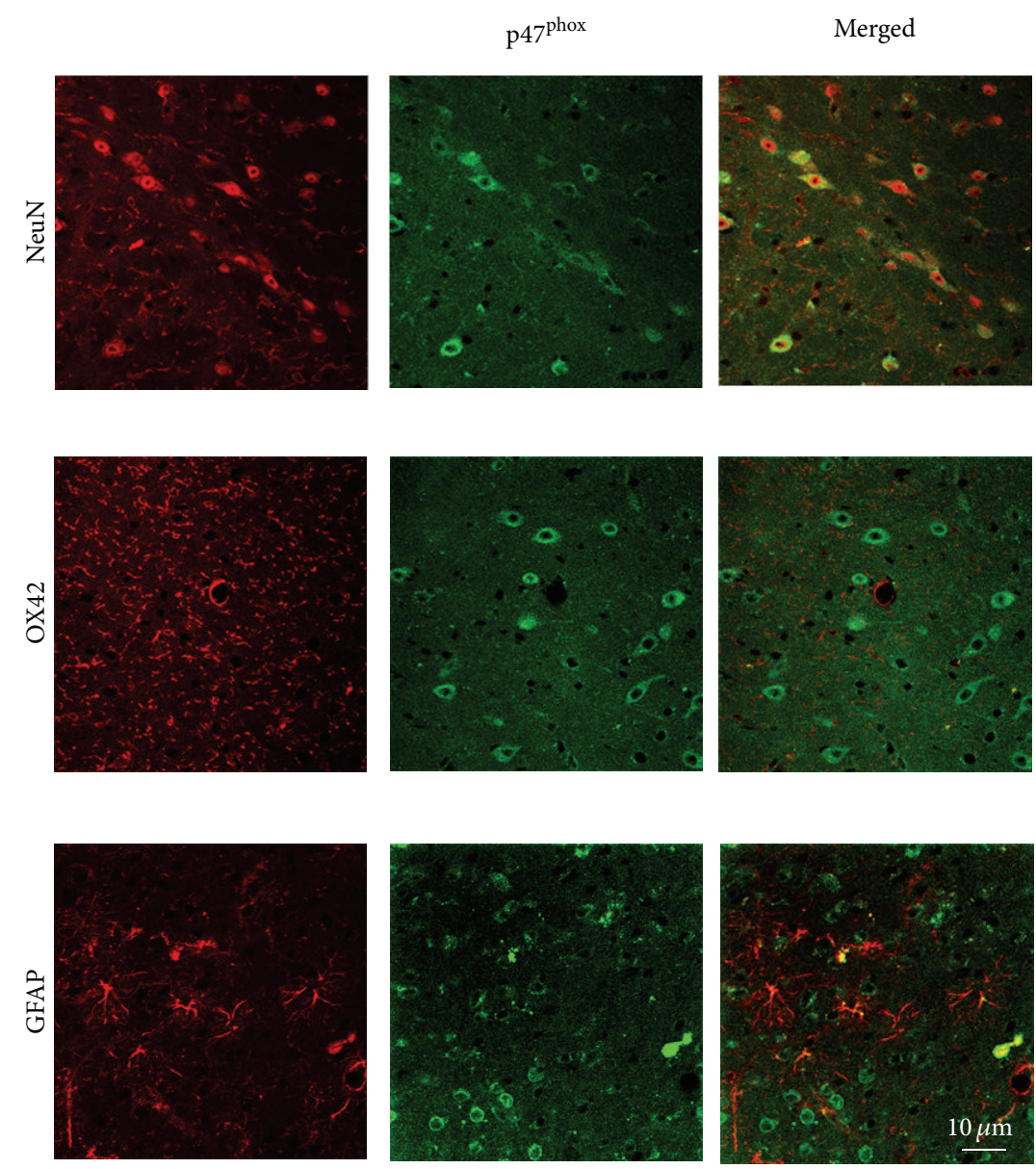

(a)

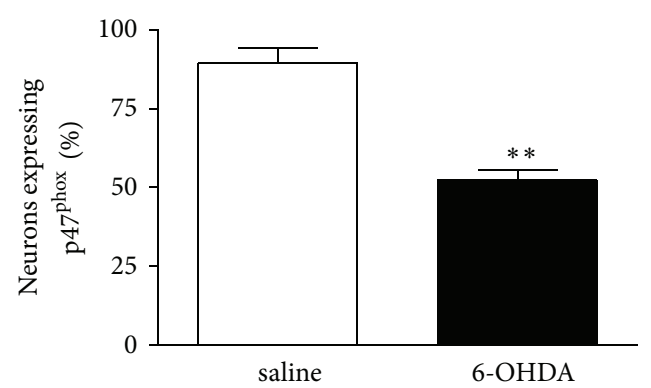

(b)

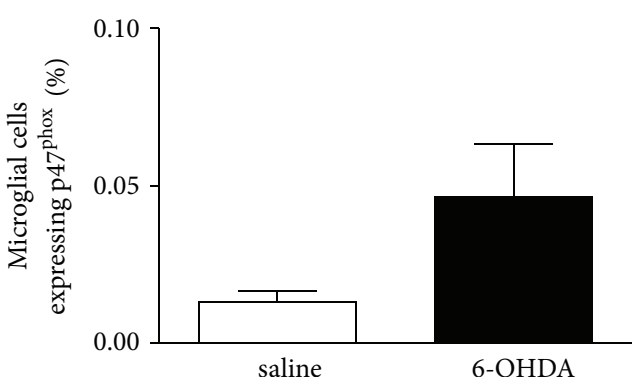

(c)

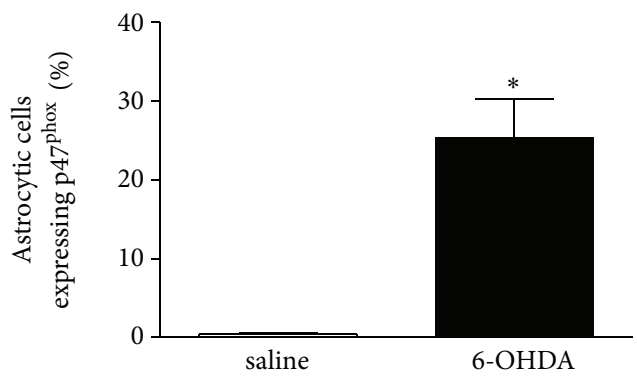

$$
\begin{aligned}
& \square \text { Saline } \\
& \text { - 6-OHDA }
\end{aligned}
$$

FIGURE 3: Expression of $47^{\text {phox }}$ in SNpc of Wt mice after 6-OHDA injection. (a) representative p47 $7^{\text {phox }}$ immunostaining in neurons and astrocytic cells. Immunostaining was carried out using antibodies for $\mathrm{p} 47^{\text {phox }}$ (shown in green) together with NeuN (top), OX42 (middle), and GFAP (bottom). Microglia, astrocyte, and neuronal markers are shown in red. In SNpc, p47 ${ }^{\text {phox }}$-positive cells are basically neurons and astrocytes; however, no $47^{\text {phox }}$-positive cells are OX42-positive cells, thus excluding their microglial origin. In (b), (c), and (d) the graphs represent the percentage of neurons, microglial cells and astrocytic cells expressing $\mathrm{p} 47^{\text {phox }}$, respectively. ${ }^{*} P<0.05$ and ${ }^{* *} P<0.01$ (Wt saline versus Wt 6-OHDA).

into membrane and cytosolic components and examined by Western blotting. As shown in Figure 1, in striatum 6-OHDA induced increased cytosolic and membrane expression of $\mathrm{p} 47^{\text {phox }}$, indicating translocation and activation of the complex, whereas in SN we observed decreased cytosolic protein levels of $\mathrm{p} 47^{\text {phox }}$. Six-OHDA did not change the $\mathrm{p} 47^{\text {phox }}$ membrane protein levels in SN.

To determine the cellular localization of $\mathrm{p} 47^{\text {phox }}$, brain sections containing striatum and $\mathrm{SN}$ were examined by double-immunofluorescence staining under confocal microscopy using a $47^{\text {phox }}$ antibody and NeuN, OX42 or GFAP antibodies, markers of neurons, microglial cell, and astrocytes, respectively. In Wt saline-injected mice, slight $\mathrm{p} 47^{\text {phox }}$ immunoreactivity was observed throughout the SN and striatum (Figure 1(b)) and was found to be predominantly located in neurons (data not shown). $\mathrm{p} 47^{\text {phox }}$ immunostaining was found to be strongly increased within striatum of 6-OHDA-injected Wt mice (Figure 1(b)). In agreement with our immunoblotting data, the density of $\mathrm{p} 47^{\text {phox }}$-positive cells was decreased in SN after 6-OHDA injection, possibly due to nigral cell death induced by 6-OHDA (Figure 1(b)). In the striatum of 6-OHDA-injected Wt mice, $\mathrm{p} 47^{\text {phox }}$ was observed in neurons and microglial cells, but not in astrocytes (Figure 2). In the SN, p47 ${ }^{\text {phox }}$ was 


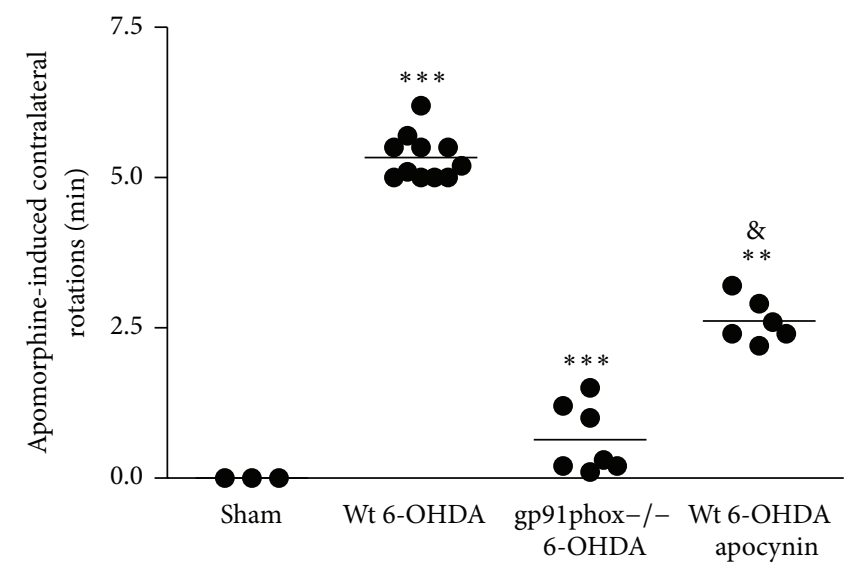

FIGURE 4: Apomorphine-induced rotation in 6-OHDA-lesioned mice. The graph depicts the number of rotations to the side contralateral to the lesion per minute. ${ }^{* * *} P<0.001$ sham versus Wt 6-OHDA; ${ }^{* * *} P<0.001 \mathrm{Wt} 6$-OHDA versus gp91 ${ }^{\text {phox }-/-} 6$-OHDA; $P<0.01$ Wt 6-OHDA versus Wt 6-OHDA apocynin; and ${ }^{\&} P<0.05$ gp91 ${ }^{\text {phox-l- }}$ 6-OHDA versus Wt 6-OHDA apocynin.
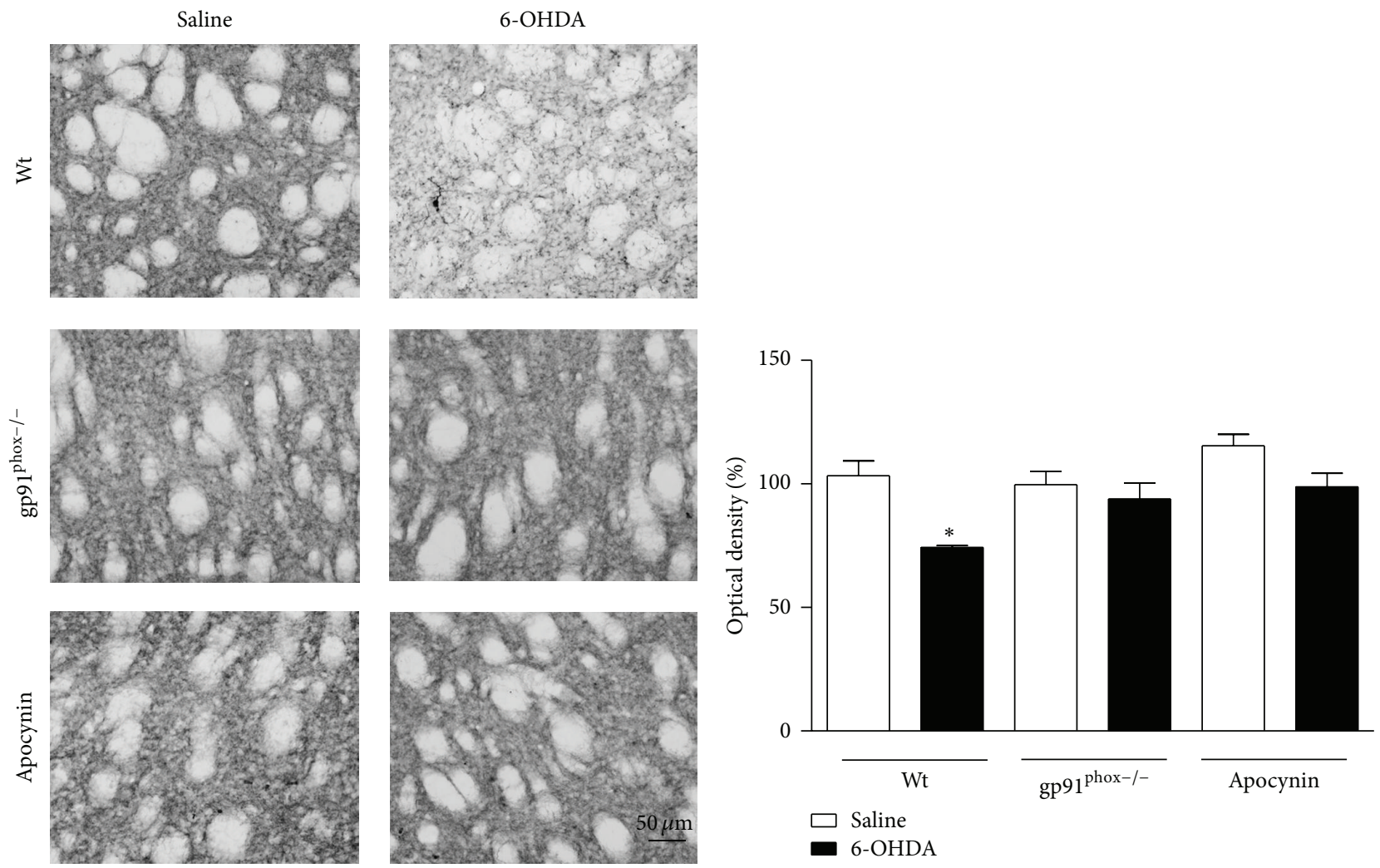

(a)

(b)

FIGURE 5: Effects of 6-OHDA on TH immunoreactivity in the striatum. (a) representative digital images of TH immunoreactivity in the salineinjected Wt, 6-OHDA-injected Wt, saline-injected gp91 $1^{\text {phox-l-}}, 6-\mathrm{OHDA}$-injected gp91 ${ }^{\text {phox- } /-}$, apocynin-treated Wt injected with saline, and apocynin-treated Wt injected with 6-OHDA. The graph depicts the mean optical density data of 4 to 5 samples in each case. ${ }^{*} P<0.05$ (Wt saline versus Wt 6-OHDA).

found in neurons and in astrocytic cells (Figure 3). These results demonstrate that expression of Nox2 is increased in striatum after 6-OHDA-induced $\mathrm{PD}$, which validates the use of the 6-OHDA as an experimental model to study the involvement of Nox 2 in the PD neurodegenerative process.
3.2. Apomorphine-Induced Rotation Test. The apomorphineinduced rotation test was performed at day 14 after lesion. Some mice showed stereotyped behaviors, such as sniffing and gnawing after administration of apomorphine. Shamoperated mice exhibited a rotation score of $0.40 \pm 0.49$, 

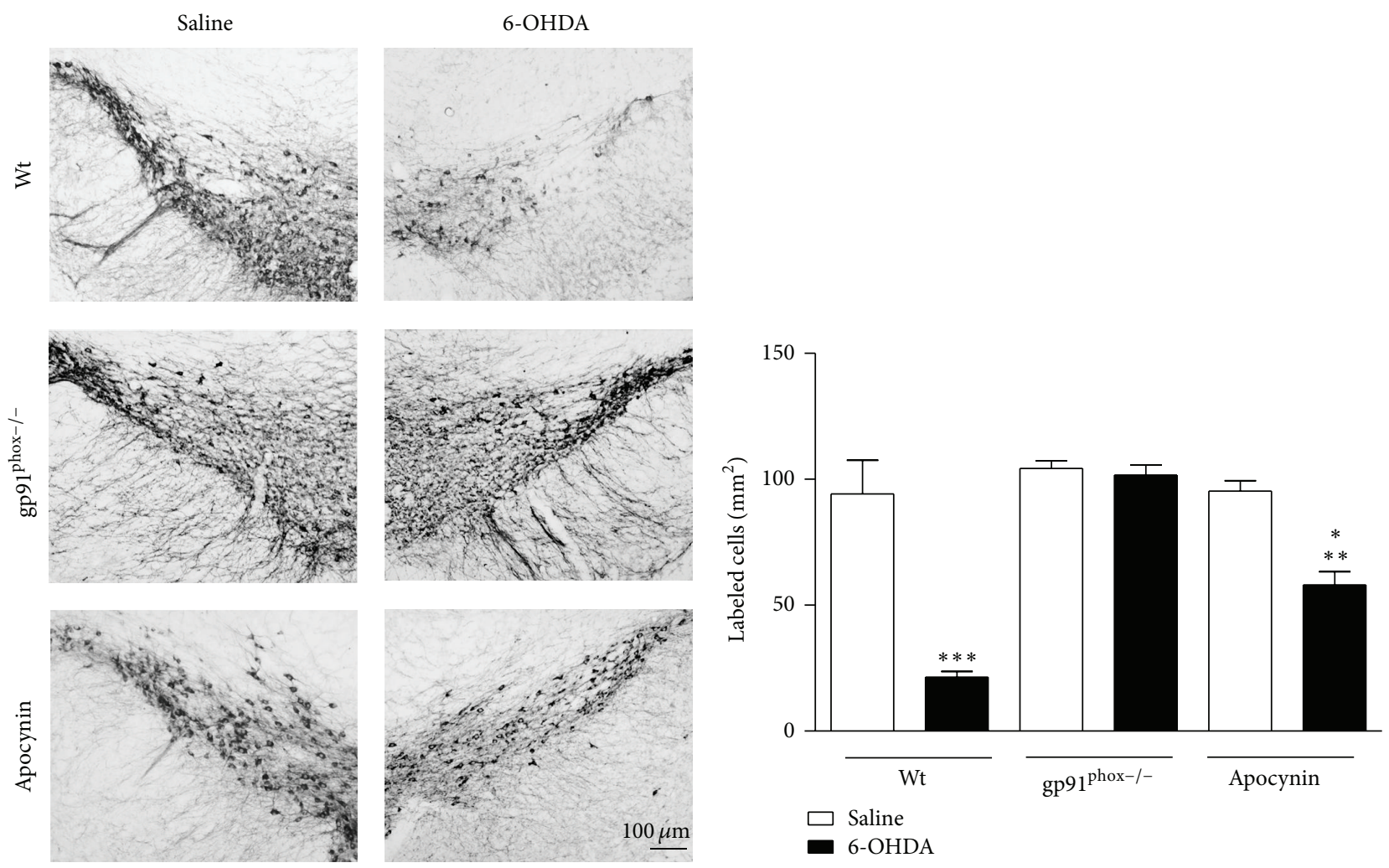

(a)

(b)

FIGURE 6: Effects of 6-OHDA on TH immunoreactivity in the SNpc. (a) representative digital images of TH immunoreactivity in mice of the groups: the saline-injected Wt, 6-OHDA-injected Wt, saline-injected gp91 phox- $/-^{\text {p-OHDA-injected gp91 }}{ }^{\text {phox- } /-}$, apocynin-treated Wt injected with saline, and apocynin-treated Wt injected with 6-OHDA. (b) the graph depicts the mean optical density data of 5 to 7 samples in each case. ${ }^{* * *} P<0.001$ (Wt saline versus Wt 6 -OHDA), ${ }^{* *} P<0.01$ (Wt apocynin saline versus Wt apocynin $6-\mathrm{OHDA}$ ), and ${ }^{*} P<0.05 \mathrm{Wt}$ apocynin 6-OHDA versusgp91 ${ }^{\text {phox-/- }}$ 6-OHDA).

whereas Wt 6-OHDA-lesioned mice showed a mean rotation score towards the control side of $5.33 \pm 0.38$. Gp91 ${ }^{\text {phox }-/-}$ 6-OHDA-lesioned mice showed a mean rotation score of $0.87 \pm 0.53$, whereas 6-OHDA-lesioned Wt mice treated with apocynin had a mean rotation score of $2.61 \pm 0.48$ (Figure 4).

3.3. Semiquantitative Analyses of TH-Immunoreactive Fibers in the Striatum and TH-Immunoreactive Cell Bodies in the $S N p c$. TH-immunolabeling data indicated that the unilateral 6-OHDA injections into the striatum significantly reduced the number of dopaminergic neurons in the SNpc by $82 \%$ and of TH staining into the striatum of Wt mice by $29 \%$. Both SNpc and striatal exposure of gp91 $1^{\text {phox-/- }}$ mice to 6OHDA did not result in significant neuronal loss. Apocynin treatment significantly prevented dopaminergic cell loss in the SNpc (by 39\%) and completely recovered TH staining in the striatum (Figures 5 and 6). However, in SNpc, a significant difference between the apocynin-treated and the gp91 $1^{\text {phox-l- }}$ 6-OHDA-lesioned mice groups was found. The treatment with apocynin was able to confer only a limited neuroprotection in comparison with the lesioned gp91 $1^{\text {phox }-/-}$ mice group.
3.4. Immunohistochemistry. In 6-OHDA-injected Wt mice we observed a marked microglial activation within the striatum (36\%) and SNpc (46\%) compared to Wt saline-injected mice. In contrast, in gp91 ${ }^{\text {phox-l- }}$ 6-OHDA-lesioned mice the microglial activation in both structures was negligible when compared to gp91 ${ }^{\text {phox-/- }}$ saline-injected mice. Apocynintreated mice showed significantly decreased microglial activation (Figures 7 and 8). Analysis of GFAP immunostaining revealed an increase of GFAP immunostaining into striatum (48\%) and SNpc (37\%) of Wt 6-OHDA-lesioned mice, which was not reduced by apocynin treatment. In $\mathrm{gp} 91^{\text {phox- } /-}$ mice, 6-OHDA injection did not increase GFAP immunostaining either in the SNpc or in the striatum (Figures 9 and 10).

\section{Discussion}

The Nox family of superoxide and hydrogen peroxideproducing proteins has emerged as an important source of ROS in neurodegenerative conditions [23]. Seven Nox isoforms have been identified, namely, Nox1, Nox2 (also known as gp91 $\left.{ }^{\text {phox }}\right)$, Nox3, Nox4, Nox5, and dual oxidase 1 and 2 (Duoxl and Duox2), each one with its own specific regulatory subunities and mechanisms. So far, only the presence of 


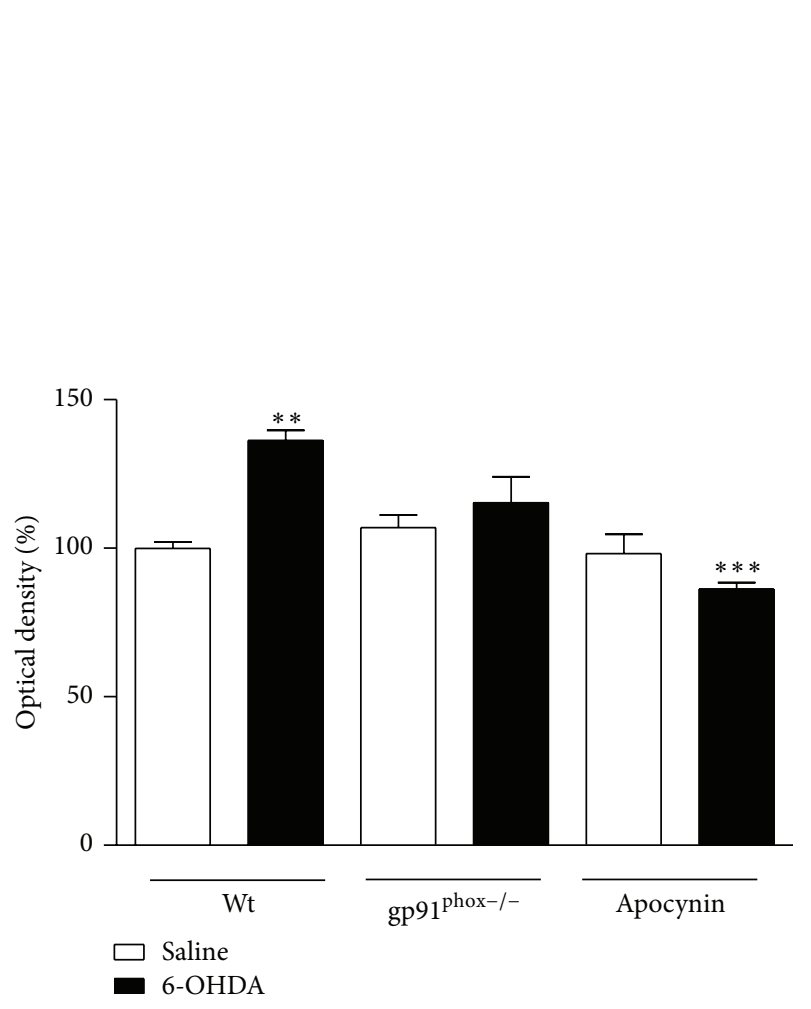

(a)
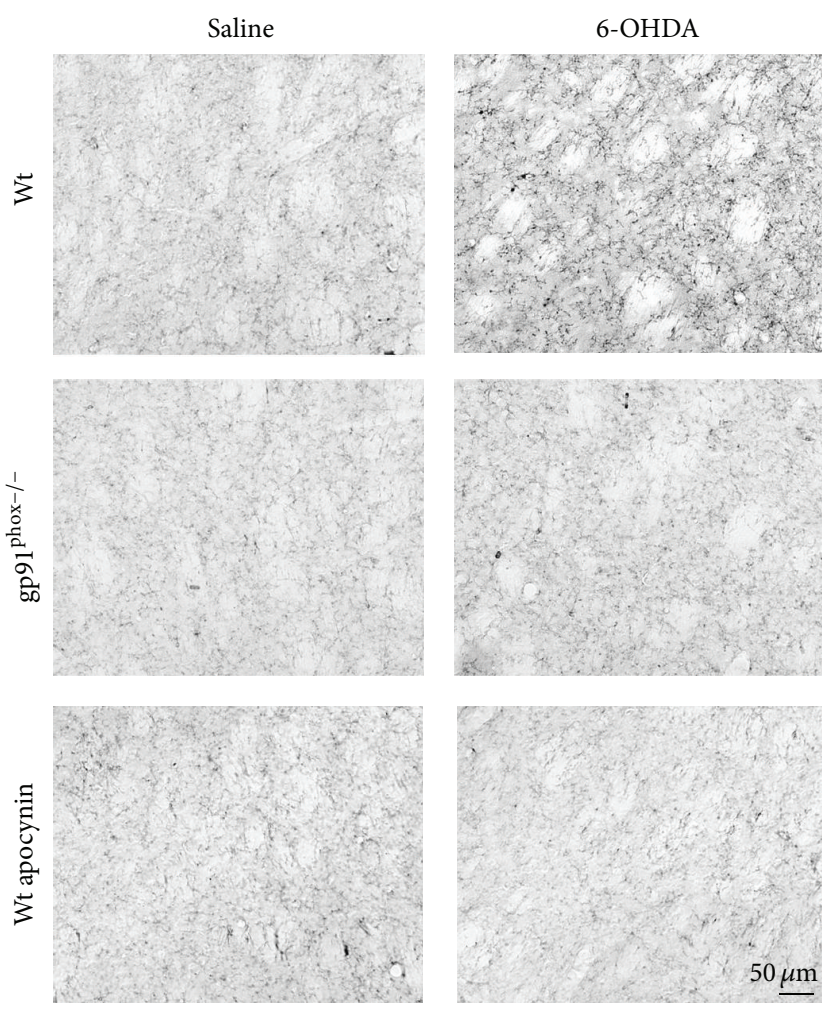

(b)

Figure 7: Effects of 6-OHDA on OX42 expression in the striatum. (a) the graph depicts the mean optical density data of 5 to 6 samples in each case. ${ }^{* *} P<0.01$ (Wt saline versus Wt 6-OHDA) and ${ }^{* * *} P<0.001$ (Wt 6-OHDAversusWt apocynin 6-OHDA). (b) representative digital images of OX42-like immunoreactivity in the saline-injected Wt, 6-OHDA-injected Wt, saline-injected gp91 ${ }^{\text {phox }}, 6$-OHDA-injected gp91 ${ }^{\text {phox-/-}}$, apocynin-treated Wt injected with saline, and apocynin-treated Wt injected with 6-OHDA mice.

Noxl/4 isoforms has been described in the central nervous system (reviewed by [24]). Structurally, all members of the Nox family contain a multisubunit structure, with catalytic flavin-binding Nox subunits and a number of regulatory subunits.

The initial experiments performed here demonstrated that the membrane protein levels of $\mathrm{p} 47^{\text {phox }}$, a cytosolic subunit of the Nox complex, are elevated in striatum of 6-OHDA-lesioned mice, suggesting that this subunit did translocate from the cytosol to the plasma membrane, assembling the functional oxidase capable of producing superoxide. It has been previously demonstrated that 1-methyl4-phenyl-1,2,3,6-tetrahydropyridine (MPTP) stimulates the translocation of the subunit $\mathrm{p} 67^{\text {phox }}$ from the cytosol to the plasma membrane in the SNpc of Wt mice [25]. The levels of $\mathrm{p} 67^{\text {phox }}$ were also found to be increased in spinal cord extracts from transgenic superoxide dismutase 1 (SOD1) mice, a genetic animal model of amyotrophic lateral sclerosis [26]. Our double immunofluorescence and confocal microscopy assays also revealed that $\mathrm{p} 47^{\text {phox }}$ is expressed in neurons and microglial cells and less often in astrocytes of the striatum. In the SN, $\mathrm{p} 47^{\text {phox }}$ was basically found in neurons. Similar results have also been described in rat mesencephalic cultures 24 hours after the treatment with 6-OHDA [12].
Apocynin is a natural organic compound widely used as a Nox2 activation inhibitor. However, the use of this compound as a specific Nox 2 inhibitor remains controversial, since the translocation of the cytosolic subunits is a mechanism required for the activation of at least Noxl and Nox 2 isoforms. Whether apocynin is also able to inhibit the constitutive activity of Nox4 is still a matter of investigation [27].

Despite the apocynin lack of specificity between Nox isoforms, in nonphagocytic cells it has been suggested that this compound acts predominantly as an antioxidant rather than a Nox inhibitor [27]. Apocynin is activated by myeloperoxidases or $\mathrm{H}_{2} \mathrm{O}_{2}$, resulting in the formation of a covalent apocynin dimer, known as diapocynin. Apocynin dimers are able to inhibit the Nox complex by oxidizing thiols of the subunit $\mathrm{p} 47^{\text {phox }}$. Thus, the inhibitory effect of apocynin on Noxes seems to be restricted to cells that produce $\mathrm{H}_{2} \mathrm{O}_{2}$ and/or express myeloperoxidases. Endothelial cells and smooth muscle cells, for example, failed to produce diapocynin in vitro [27]. In the nervous system, following a single intraperitoneal injection of apocynin $(5 \mathrm{mg} / \mathrm{kg})$, no diapocynin was detected in brain samples of rats within 30 min to 2 hours after administration [28]. On the other hand, another study has shown that after the chronic treatment with apocynin $(150 \mathrm{mg} / \mathrm{kg}$ in the drinking water for 100 


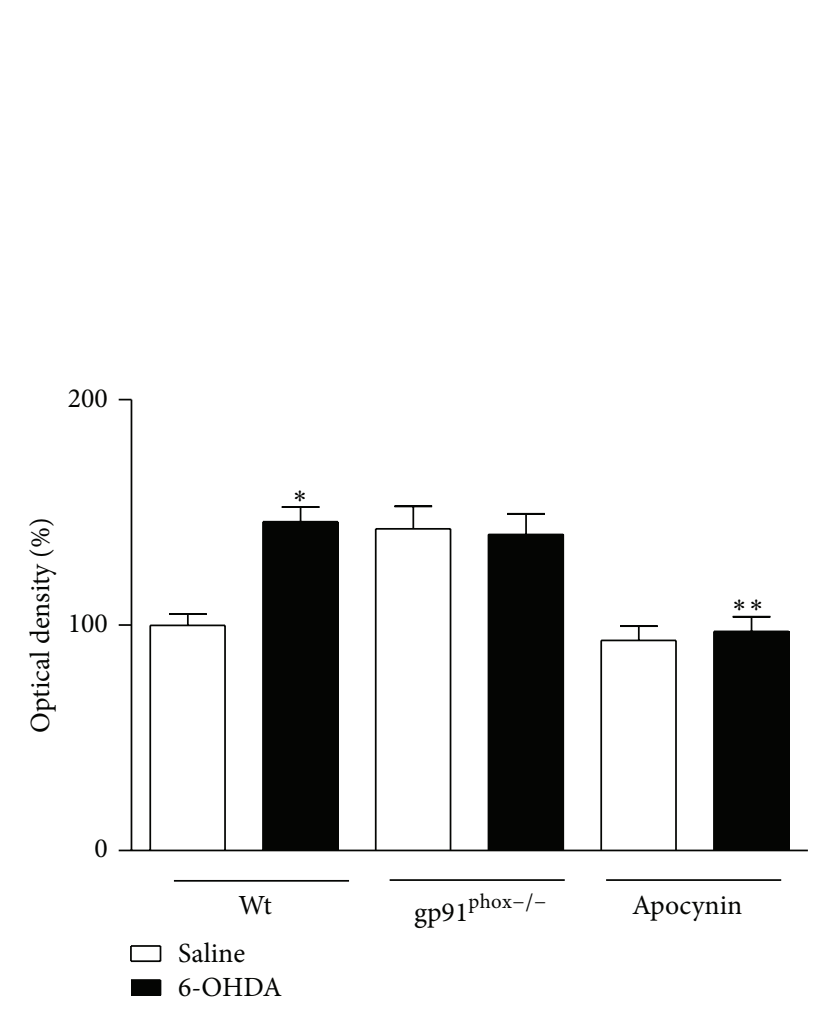

(a)
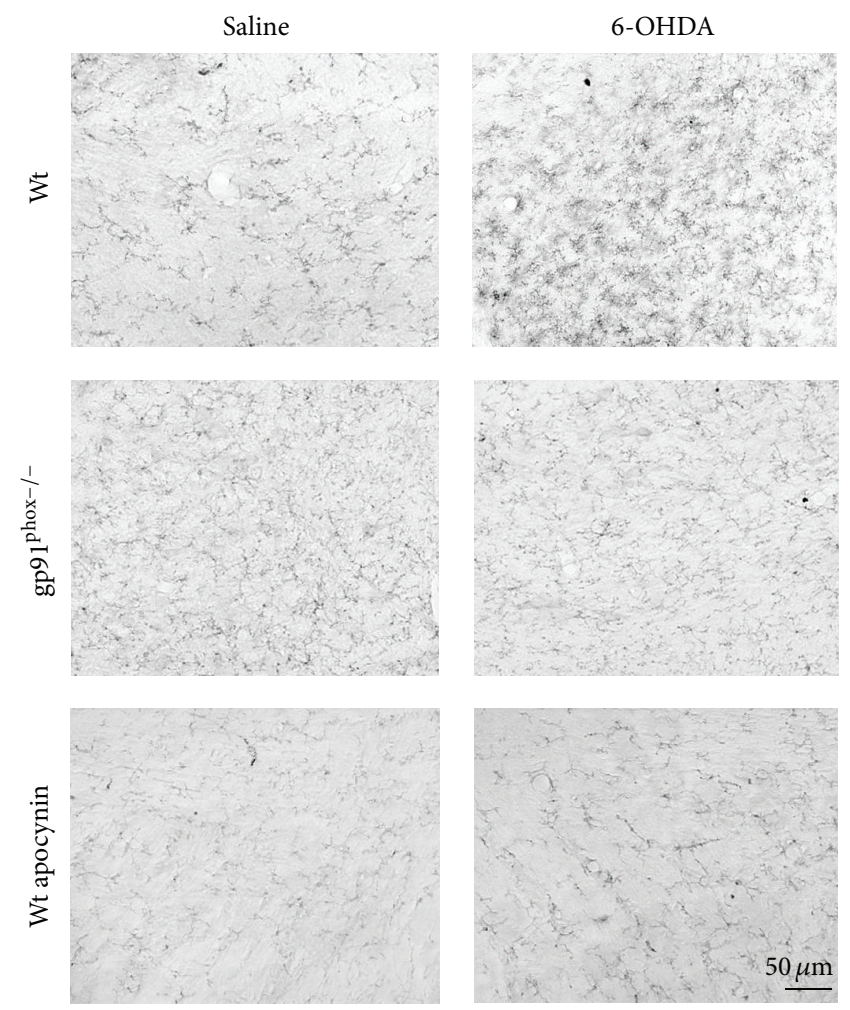

(b)

Figure 8: Effects of 6-OHDA on OX42 expression in the SNpc. (a) the graph depicts the mean optical density data of 5 to 6 samples in each case. ${ }^{*} P<0.05$ (Wt saline versus Wt 6-OHDA) and ${ }^{* *} P<0.01$ (Wt 6-OHDA versus Wt apocynin 6-OHDA). (b) representative digital images of OX42-like immunoreactivity in the saline-injected Wt, 6-OHDA-injected Wt, saline-injected gp91 ${ }^{\text {phox }}$, 6-OHDA-injected gp91 ${ }^{\text {phox-I- }}$, apocynin-treated Wt injected with saline, and apocynin-treated Wt injected with 6-OHDA mice.

days), micromolar concentrations of diapocynin were found accumulated in the brain tissue of transgenic SOD1 mutant mice. Its content represented about $7-8 \%$ of the total apocynin concentration [29]. Although there are some experimental evidence describing the neuroprotective effects of apocynin under different models of PD [12,30,31], more detailed studies elucidating the production of diapocynin in brain structures affected by this neurodegenerative condition are needed to elucidate whether these promising findings are related to Nox inhibition rather than apocynin antioxidant effects. Considering the apocynin lack of specificity and elusive mechanism of action, in the present study, we sought to compare the effect of 6-OHDA-induced PD in mutant mice lacking gp91 ${ }^{\text {phox }}$ and by the pharmacological inhibition of the Nox complex with apocynin.

Since unilateral 6-OHDA injection causes a quantifiable rotational behavior induced by systemic administration of dopaminergic receptor agonists such as apomorphine [32], we further analyzed the extent of the dopaminergic lesion induced by this neurotoxin. We found in the present study that both gp91 ${ }^{\text {phox-/- }}$ 6-OHDA-lesioned mice and Wt 6OHDA-lesioned mice chronically treated with apocynin exhibited significantly ameliorated neurotoxin-induced rotational behavior in comparison with Wt mice. However, the expression of contralateral turnings after systemic injections of apomorphine between gp91 $1^{\text {phox-/- }}$ 6-OHDA-lesioned mice and Wt 6-OHDA-lesioned mice chronically treated with apocynin was found to be different. Gp91 ${ }^{\text {phox-l- }}$ presented a significantly reduced rotation score when compared to the apocynin-treated mice group.

We also found a positive relationship between apomorphine-induced rotational behavior and TH-immunoreactive cell bodies and fibers. We confirmed that the administration of apocynin was able to attenuate dopaminergic neurodegeneration induced by 6-OHDA in SNpc and from the dopaminergic terminal loss in striatum. However, gp91 ${ }^{\text {phox-l- }}$ mice appear to be completely protected from the dopaminergic cell loss induced by 6-OHDA in the SNpc, an effect significantly different from the effect observed in the apocynin-treated group. Regarding the use of gp91 ${ }^{\text {phox-/- }}$ mice, our results are in accordance with an earlier study in which it was demonstrated that these knockout mice exhibited less SNpc dopaminergic neuronal losses and protein oxidation than Wt mice after MPTP injections [25]. Furthermore, primary mesencephalic cultures from gp $91^{\text {phox-/- }}$ mice were more resistant to rotenone neurotoxicity than those from Wt mice [30]. 


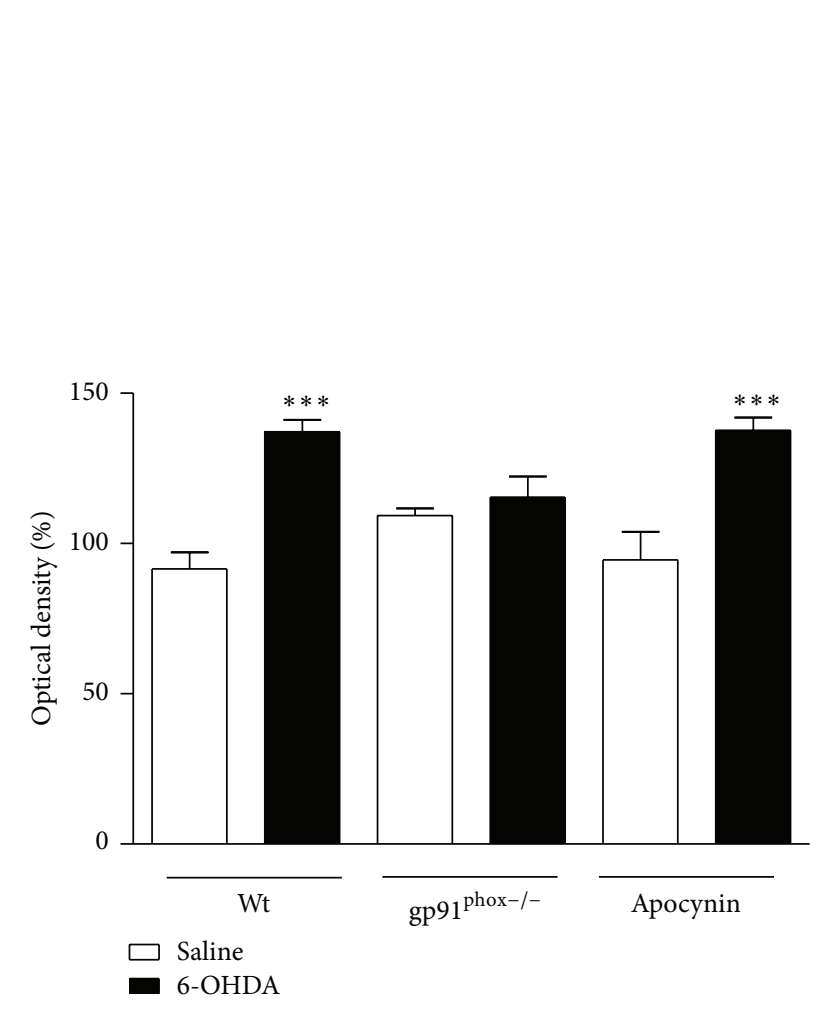

(a)
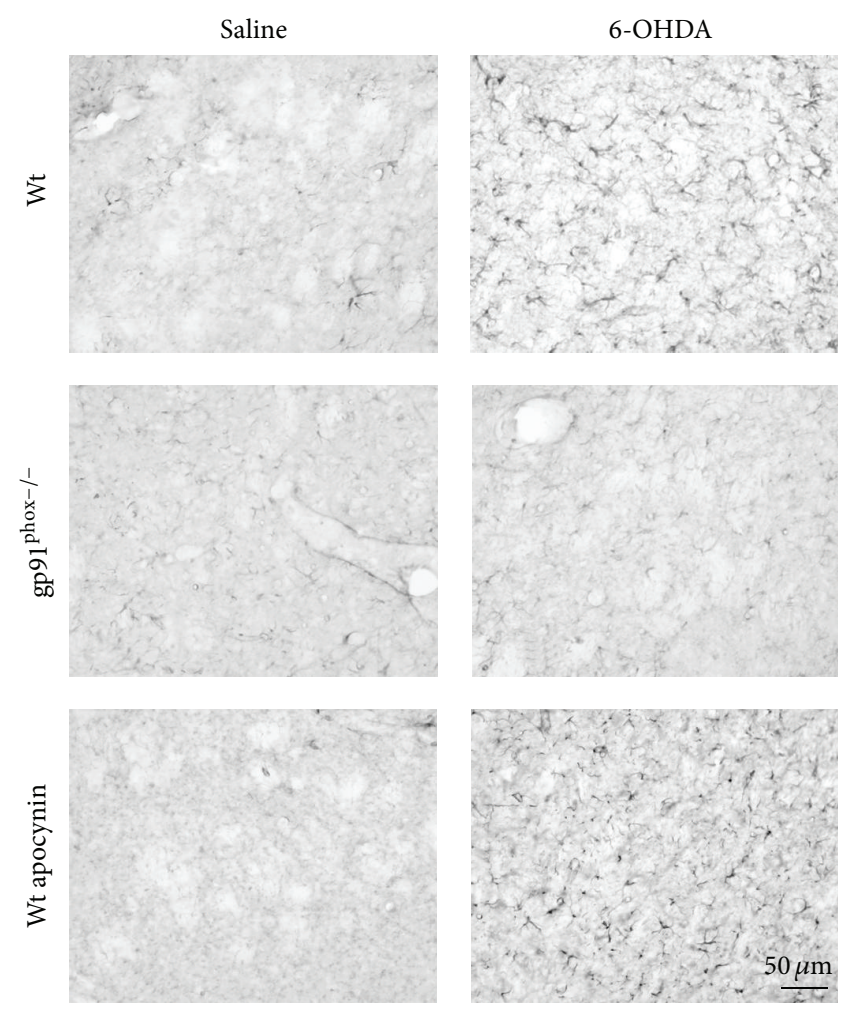

(b)

FIGURE 9: Effects of 6-OHDA on GFAP expression in the striatum. (a) the graph depicts the mean optical density data of 5 to 6 samples in each case. ${ }^{* * *} P<0.001$ (Wt saline versus Wt $6-\mathrm{OHDA}$ ) and ${ }^{* * *} P<0.001$ (Wt apocynin saline versus Wt apocynin 6-OHDA). (b) representative digital images of GFAP-like immunoreactivity in the saline-injected Wt, 6-OHDA-injected Wt, saline-injected gp91 ${ }^{\text {phox }}$, 6-OHDA-injected gp91 ${ }^{\text {phox-I- }}$, apocynin-treated Wt injected with saline, and apocynin-treated Wt injected with 6-OHDA mice.

It has been previously demonstrated that, in addition to the dramatic loss of dopaminergic neurons, gliosis is a marked neuropathological feature in the SNpc and the striatum in the 6-OHDA-mouse models of PD [33-35]. In mesencephalic primary cultures, activated microglia generated Nox-derived superoxide and enhanced neurotoxinelicited dopaminergic neurodegeneration [30]. Furthermore, it was reported that inhibition of microglial activation can protect dopaminergic neurons from degeneration $[35,36]$. Immunohistochemical detection of OX42-positive cells in this study indicated a marked microglial activation in both striatum and SNpc of mice injected with 6-OHDA. Our immunostaining assays also revealed increased expression of astrocyte markers in the striatum and SNpc after 6-OHDA injection. Our data show that gp91 ${ }^{\text {phox- } /-}$ mice are protected against glial activation induced by 6-OHDA, whereas apocynin treatment was only able to prevent microglial activation.

\section{Conclusions}

In summary, our data emphasize that the Nox2-dependent oxidative stress contributes to PD-dopaminergic neurodegeneration in the nigrostriatal pathway. In addition, the experiments conducted with apocynin and mutant mice deficient in gp91 ${ }^{\text {phox }}$ collectively demonstrate no comparable 6-OHDA effects between the two mice groups. The apocynin treatment conferred only a limited protection. As an alternative to the use of unspecific Nox inhibitors, the use of knockout mice may represent several advantages to characterize the individual contribution of ROS producing systems such as Noxes.

\section{Conflict of Interests}

The authors declare that there is no conflict of interests regarding the publication of this paper.

\section{Acknowledgments}

This study was supported by FAPESP and CNPq (L.R.G.B.). Marina S. Hernandes and Cecília C. Café-Mendes were the recipients of fellowships from FAPESP. Thanks are due to Adilson S. Alves for technical assistance. The authors thank Professor Rui Curi for supplying gp9 ${ }^{\text {phox }-/-}$ mice. The authors would like to thank Dr. Mauro Leonelli for excellent technical assistance in acquiring confocal images. 


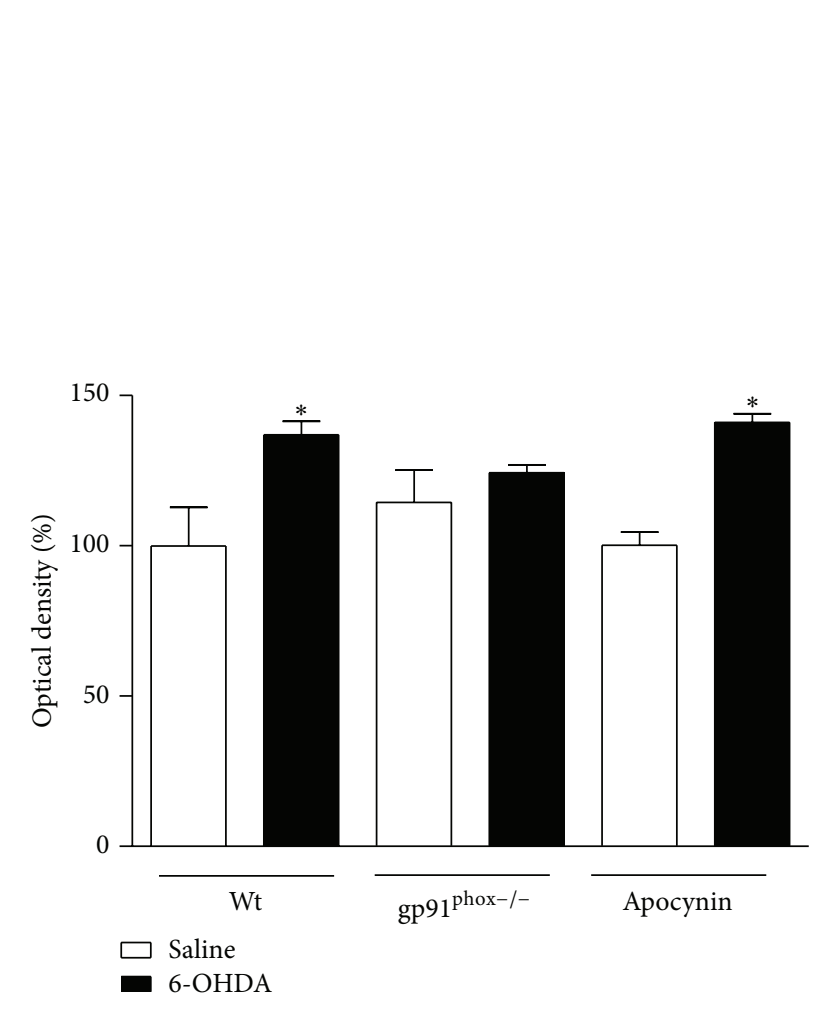

(a)
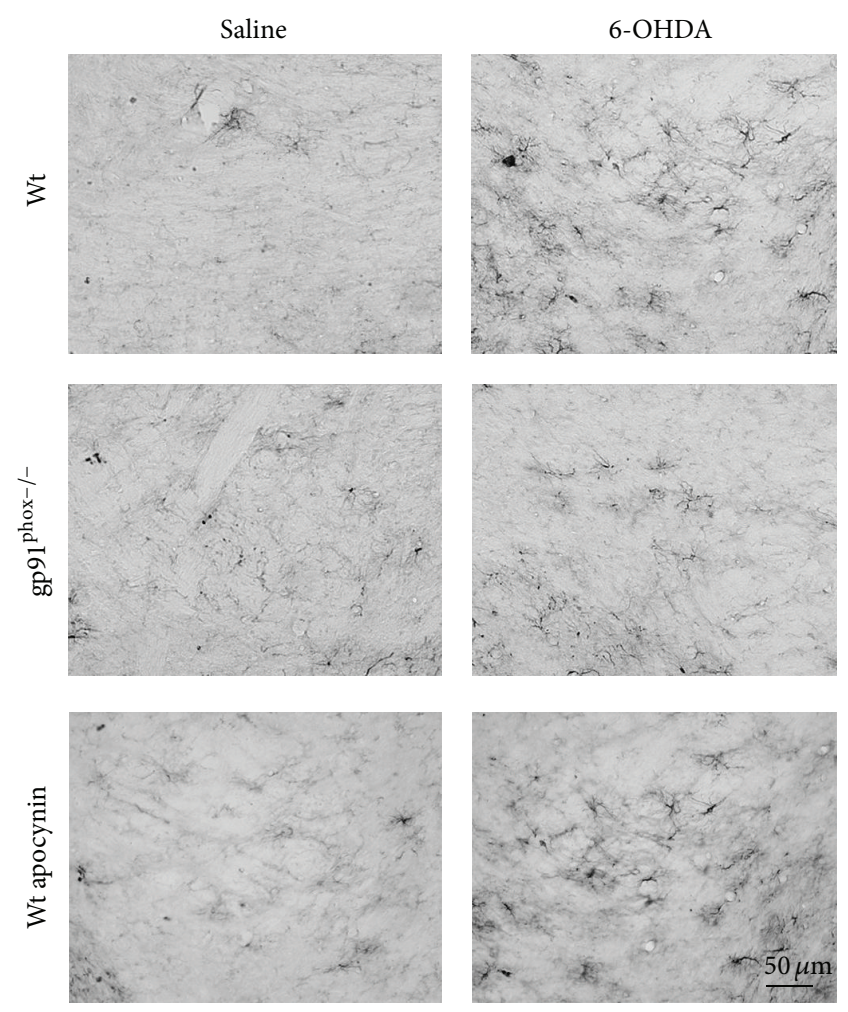

(b)

Figure 10: Effects of 6-OHDA on GFAP expression in the SNpc. (a) the graph depicts the mean optical density data of 5 to 6 samples in each case. ${ }^{*} P<0.05$ (Wt saline versus Wt 6-OHDA) and ${ }^{*} P<0.05$ (Wt apocynin saline versus Wt apocynin 6-OHDA). (b) representative digital images of GFAP-like immunoreactivity in the saline-injected Wt, 6-OHDA-injected Wt, saline-injected gp91 ${ }^{\text {phox }}, 6$-OHDA-injected gp91 ${ }^{\text {phox-I- }}$, apocynin-treated Wt injected with saline, and apocynin-treated Wt injected with 6-OHDA mice.

\section{References}

[1] W. Dauer and S. Przedborski, "Parkinson's disease: mechanisms and models," Neuron, vol. 39, no. 6, pp. 889-909, 2003.

[2] J. T. Greenamyre and T. G. Hastings, "Parkinson's-divergent causes, convergent mechanisms," Science, vol. 304, no. 5674, pp. $1120-1122,2004$.

[3] P. Jenner, "Oxidative stress in Parkinson's disease," Annals of Neurology, vol. 53, supplement 3, pp. S26-S38, 2003.

[4] A. Yoritaka, N. Hattori, K. Uchida, M. Tanaka, E. R. Stadtman, and Y. Mizuno, "Immunohistochemical detection of 4hydroxynonenal protein adducts in Parkinson disease," Proceedings of the National Academy of Sciences of the United States of America, vol. 93, no. 7, pp. 2696-2701, 1996.

[5] Z. I. Alam, S. E. Daniel, A. J. Lees, D. C. Marsden, P. Jenner, and B. Halliwell, "A generalised increase in protein carbonyls in the brain in Parkinson's but not incidental Lewy body disease," Journal of Neurochemistry, vol. 69, no. 3, pp. 1326-1329, 1997.

[6] E. Floor and M. G. Wetzel, "Increased protein oxidation in human substantia nigra pars compacta in comparison with basal ganglia and prefrontal cortex measured with an improved dinitrophenylhydrazine assay," Journal of Neurochemistry, vol. 70, no. 1, pp. 268-275, 1998.

[7] B. I. Giasson, J. E. Duda, I. V. J. Murray et al., "Oxidative damage linked to neurodegeneration by selective $\alpha$-synuclein nitration in synucleinopathy lesions," Science, vol. 290, no. 5493, pp. 985989, 2000.
[8] P. F. Good, A. Hsu, P. Werner, D. P. Perl, and C. Warren Olanow, "Protein nitration in Parkinson's disease," Journal of Neuropathology and Experimental Neurology, vol. 57, no. 4, pp. 338-342, 1998.

[9] A. Schober, "Classic toxin-induced animal models of Parkinson's disease: 6-OHDA and MPTP," Cell and Tissue Research, vol. 318, no. 1, pp. 215-224, 2004.

[10] F. Blandini, M.-T. Armentero, and E. Martignoni, "The 6hydroxydopamine model: news from the past," Parkinsonism and Related Disorders, vol. 14, no. 2, pp. S124-S129, 2008.

[11] U. Ungerstedt, "6-hydroxy-dopamine induced degeneration of central monoamine neurons," European Journal of Pharmacology, vol. 5, no. 1, pp. 107-110, 1968.

[12] J. Rodriguez-Pallares, J. A. Parga, A. Muñoz, P. Rey, M. J. Guerra, and J. L. Labandeira-Garcia, "Mechanism of 6hydroxydopamine neurotoxicity: the role of $\mathrm{NADPH}$ oxidase and microglial activation in 6-hydroxydopamine-induced degeneration of dopaminergic neurons," Journal of Neurochemistry, vol. 103, no. 1, pp. 145-156, 2007.

[13] D. I. Brown and K. K. Griendling, "Nox proteins in signal transduction," Free Radical Biology and Medicine, vol. 47, no. 9, pp. 1239-1253, 2009.

[14] A. C. Montezano and R. M. Touyz, "Oxidative stress, noxs, and hypertension: experimental evidence and clinical controversies," Annals of Medicine, vol. 44, supplement 1, pp. S2-S16, 2012. 
[15] T. Kahles and R. P. Brandes, "NADPH oxidases as therapeutic targets in ischemic stroke," Cellular and Molecular Life Sciences, vol. 69, no. 14, pp. 2345-2363, 2012.

[16] K. Molina-Luna, A. Pekanovic, S. Röhrich et al., "Dopamine in motor cortex is necessary for skill learning and synaptic plasticity," Plos One, vol. 4, no. 9, Article ID e7082, 2009.

[17] G. Paxinos and K. Franklin, The Mouse Brain in Stereotaxic Coordinates, Academic Press, New York, NY, USA, 2007.

[18] M. R. Zarrindast, F. Sedaghati, and F. Borzouyeh, "Nicotineinduced grooming: a possible dopaminergic and/or cholinergic mechanism," Journal of Psychopharmacology, vol. 12, no. 4, pp. 375-379, 1998.

[19] Y. Zhang, M. M. K. Chan, M. C. Andrews et al., "Apocynin but not allopurinol prevents and reverses adrenocorticotropic hormone-induced hypertension in the rat," American Journal of Hypertension, vol. 18, no. 7, pp. 910-916, 2005.

[20] H. W. Morrison and J. A. Filosa, "A quantitative spatiotemporal analysis of microglia morphology during ischemic stroke and reperfusion," Journal of Neuroinflammation, vol. 10, no. 4, pp. $10-14,2013$.

[21] M. Montaña, G. G. del Caño, M. L. de Jesús et al., "Cellular neurochemical characterization and subcellular localization of phospholipase C $\beta 1$ in rat brain," Neuroscience, vol. 222, pp. 239268, 2012.

[22] B. M. Babior, "The activity of leukocyte NADPH oxidase: regulation by $\mathrm{p} 47 \mathrm{PHOX}$ cysteine and serine residues," Antioxidants and Redox Signaling, vol. 4, no. 1, pp. 35-38, 2002.

[23] L. M. Sayre, M. A. Smith, and G. Perry, "Chemistry and biochemistry of oxidative stress in neurodegenerative disease," Current Medicinal Chemistry, vol. 8, no. 7, pp. 721-738, 2001.

[24] M. S. Hernandes and L. R. Britto, "NADPH oxidase and neurodegeneration," Current Neuropharmacology, vol. 10, no. 4, pp. 321-327, 2012.

[25] D.-C. Wu, P. Teismann, K. Tieu et al., "NADPH oxidase mediates oxidative stress in the 1-methyl-4-phenyl-1,2,3,6tetrahydropyridine model of Parkinson's disease," Proceedings of the National Academy of Sciences of the United States of America, vol. 100, no. 10, pp. 6145-6150, 2003.

[26] D.-C. Wu, D. B. Ré, M. Nagai, H. Ischiropoulos, and S. Przedborski, "The inflammatory NADPH oxidase enzyme modulates motor neuron degradation in amyotrophic lateral sclerosis mice," Proceedings of the National Academy of Sciences of the United States of America, vol. 103, no. 32, pp. 12132-12137, 2006.

[27] S. Heumüller, S. Wind, E. Barbosa-Sicard et al., "Apocynin is not an inhibitor of vascular NADPH oxidases but an antioxidant," Hypertension, vol. 51, no. 2, pp. 211-217, 2008.

[28] Q. Wang, R. E. Smith, R. Luchtefeld et al., "Bioavailability of apocynin through its conversion to glycoconjugate but not to diapocynin," Phytomedicine, vol. 15, no. 6-7, pp. 496-503, 2008.

[29] K. A. Trumbull, D. McAllister, M. M. Gandelman et al., "Diapocynin and apocynin administration fails to significantly extend survival in G93A SOD1 ALS mice," Neurobiology of Disease, vol. 45, no. 1, pp. 137-144, 2012.

[30] H.-M. Gao, B. Liu, and J.-S. Hong, "Critical role for microglial $\mathrm{NADPH}$ oxidase in rotenone-induced degeneration of dopaminergic neurons," Journal of Neuroscience, vol. 23, no. 15, pp. 6181-6187, 2003.

[31] H.-M. Gao, B. Liu, W. Zhang, and J.-S. Hong, "Critical role of microglial NADPH oxidase-derived free radicals in the in vitro MPTP model of Parkinson's disease," The FASEB Journal, vol. 17, no. 13, pp. 1954-1956, 2003.
[32] R. Iancu, P. Mohapel, P. Brundin, and G. Paul, "Behavioral characterization of a unilateral 6-OHDA-lesion model of Parkinson's disease in mice," Behavioural Brain Research, vol. 162, no. 1, pp. 1-10, 2005.

[33] G. T. Liberatore, V. Jackson-Lewis, S. Vukosavic et al., "Inducible nitric oxide synthase stimulates dopaminergic neurodegeneration in the MPTP model of Parkinson disease," Nature Medicine, vol. 5, no. 12, pp. 1403-1409, 1999.

[34] R. W. P. Rodrigues, V. C. Gomide, and G. Chadi, "Astroglial and microglial reaction after a partial nigrostriatal degeneration induced by the striatal injection of different doses of 6hydroxydopamine," International Journal of Neuroscience, vol. 109, no. 1-2, pp. 91-126, 2001.

[35] D. C. Wu, V. Jackson-Lewis, M. Vila et al., "Blockade of microglial activation is neuroprotective in the 1-methyl-4phenyl-1,2,3,6-tetrahydropyridine mouse model of Parkinson disease," Journal of Neuroscience, vol. 22, no. 5, pp. 1763-1771, 2002.

[36] H.-M. Gao, J. Jiang, B. Wilson, W. Zhang, J.-S. Hong, and B. Liu, "Microglial activation-mediated delayed and progressive degeneration of rat nigral dopaminergic neurons: relevance to Parkinson's disease," Journal of Neurochemistry, vol. 81, no. 6, pp. 1285-1297, 2002 


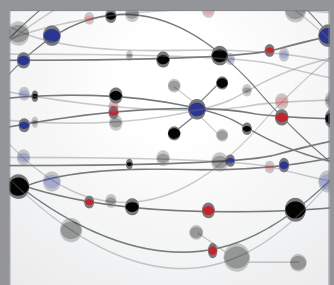

The Scientific World Journal
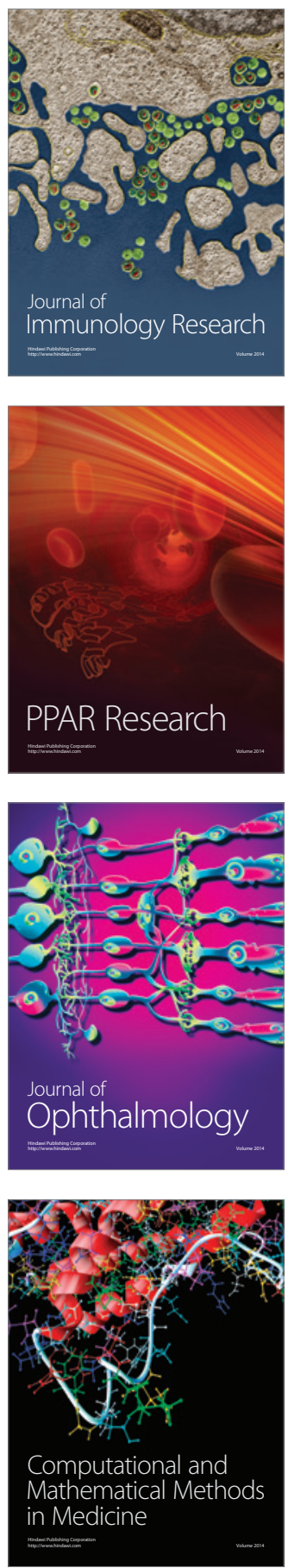

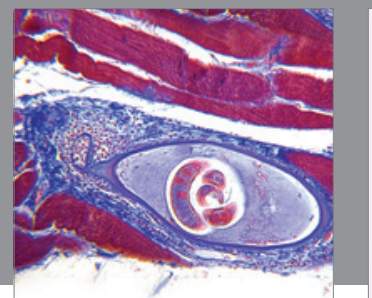

Gastroenterology

Research and Practice
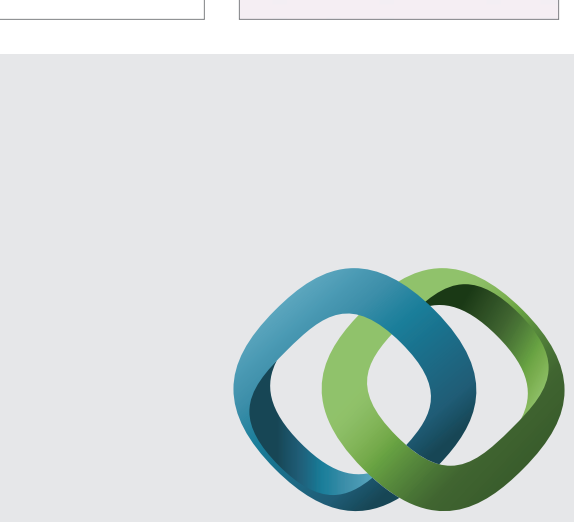

\section{Hindawi}

Submit your manuscripts at

http://www.hindawi.com
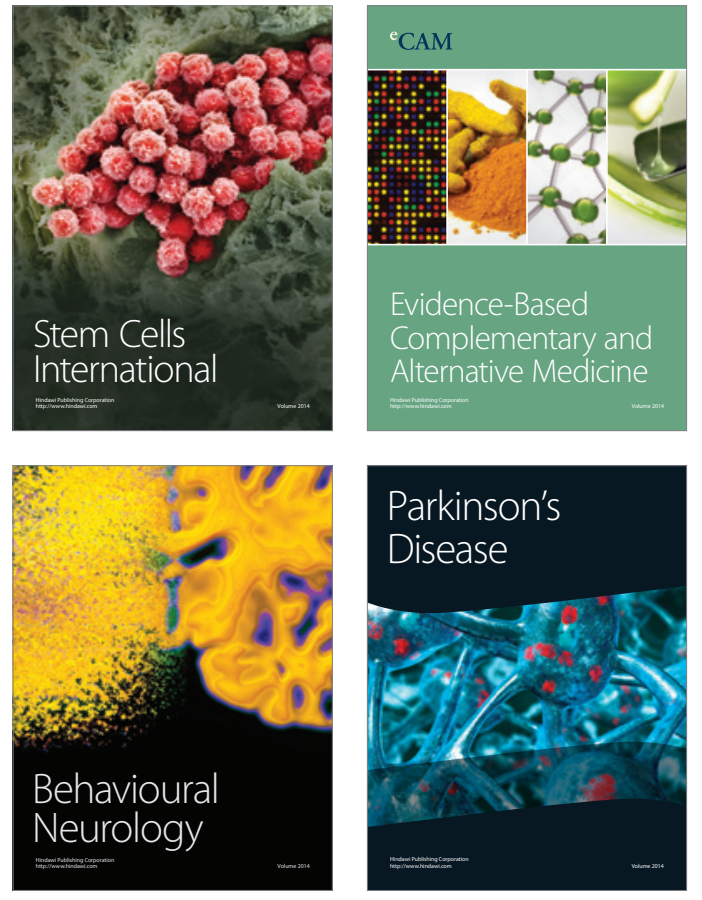
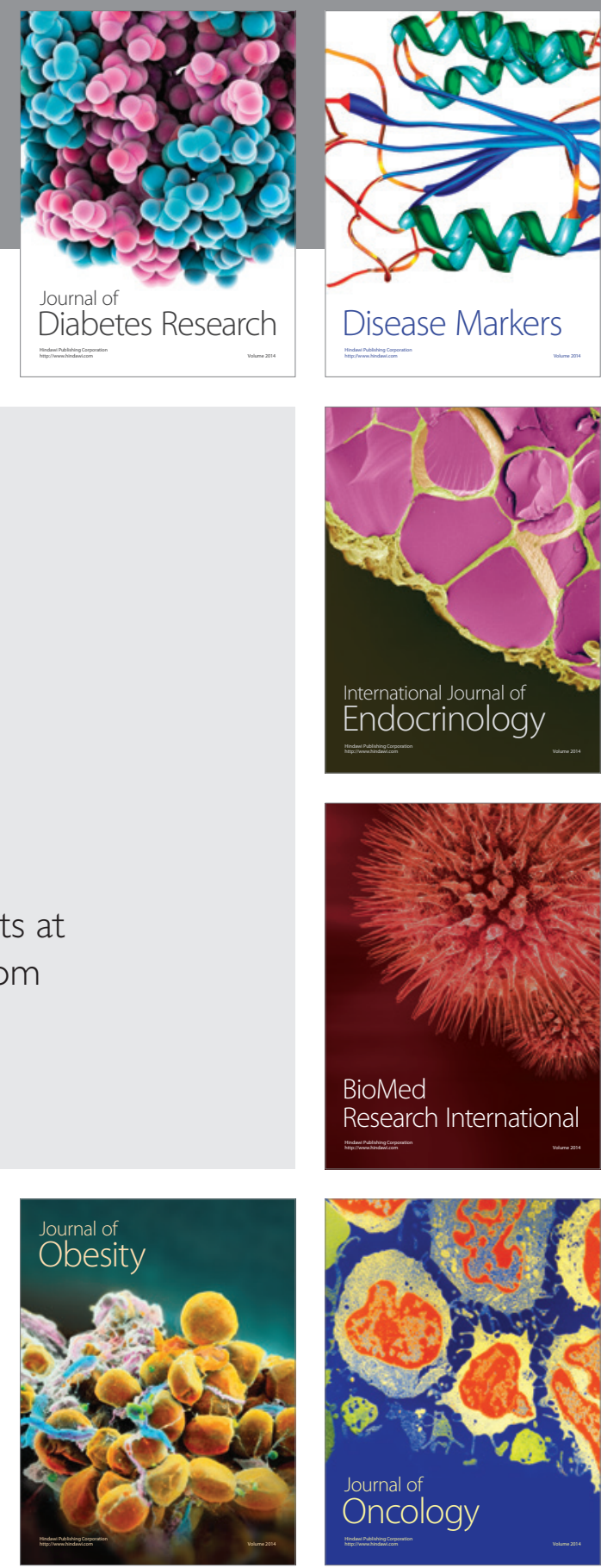

Disease Markers
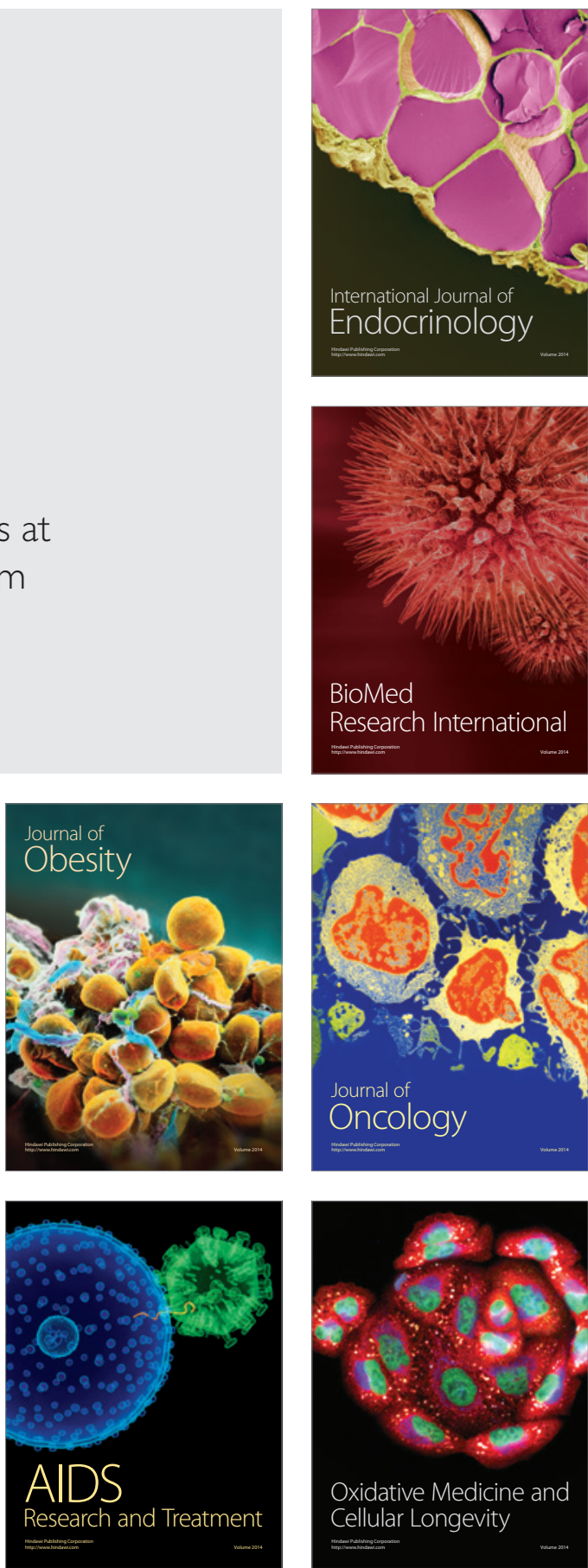